
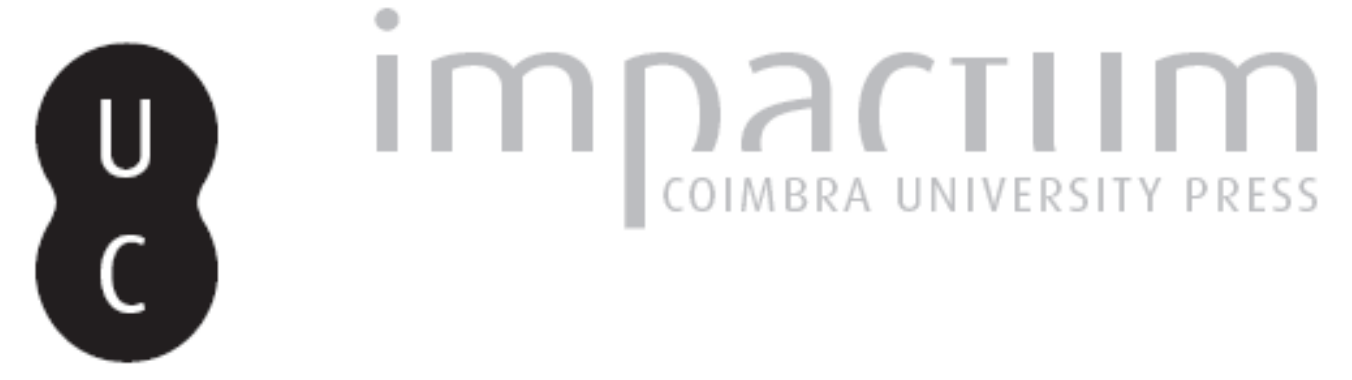

\title{
Filosofía de la Historia y Sociologia de la Religión: las posiciones de Max Weber ante la Historia Universal
}

\author{
Autor(es): $\quad$ Piedras Monroy, Pedro A.
}

Publicado por: Imprensa da Universidade de Coimbra

URL persistente:

URI:http://hdl.handle.net/10316.2/43729

DOI:

DOI:https://doi.org/10.14195/2183-8925_24_16

Accessed : $\quad$ 26-Apr-2023 01:42:10

A navegação consulta e descarregamento dos títulos inseridos nas Bibliotecas Digitais UC Digitalis, UC Pombalina e UC Impactum, pressupõem a aceitação plena e sem reservas dos Termos e Condições de Uso destas Bibliotecas Digitais, disponíveis em https://digitalis.uc.pt/pt-pt/termos.

Conforme exposto nos referidos Termos e Condições de Uso, o descarregamento de títulos de acesso restrito requer uma licença válida de autorização devendo o utilizador aceder ao(s) documento(s) a partir de um endereço de IP da instituição detentora da supramencionada licença.

Ao utilizador é apenas permitido o descarregamento para uso pessoal, pelo que o emprego do(s) título(s) descarregado(s) para outro fim, designadamente comercial, carece de autorização do respetivo autor ou editor da obra.

Na medida em que todas as obras da UC Digitalis se encontram protegidas pelo Código do Direito de Autor e Direitos Conexos e demais legislação aplicável, toda a cópia, parcial ou total, deste documento, nos casos em que é legalmente admitida, deverá conter ou fazer-se acompanhar por este aviso.

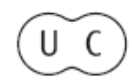



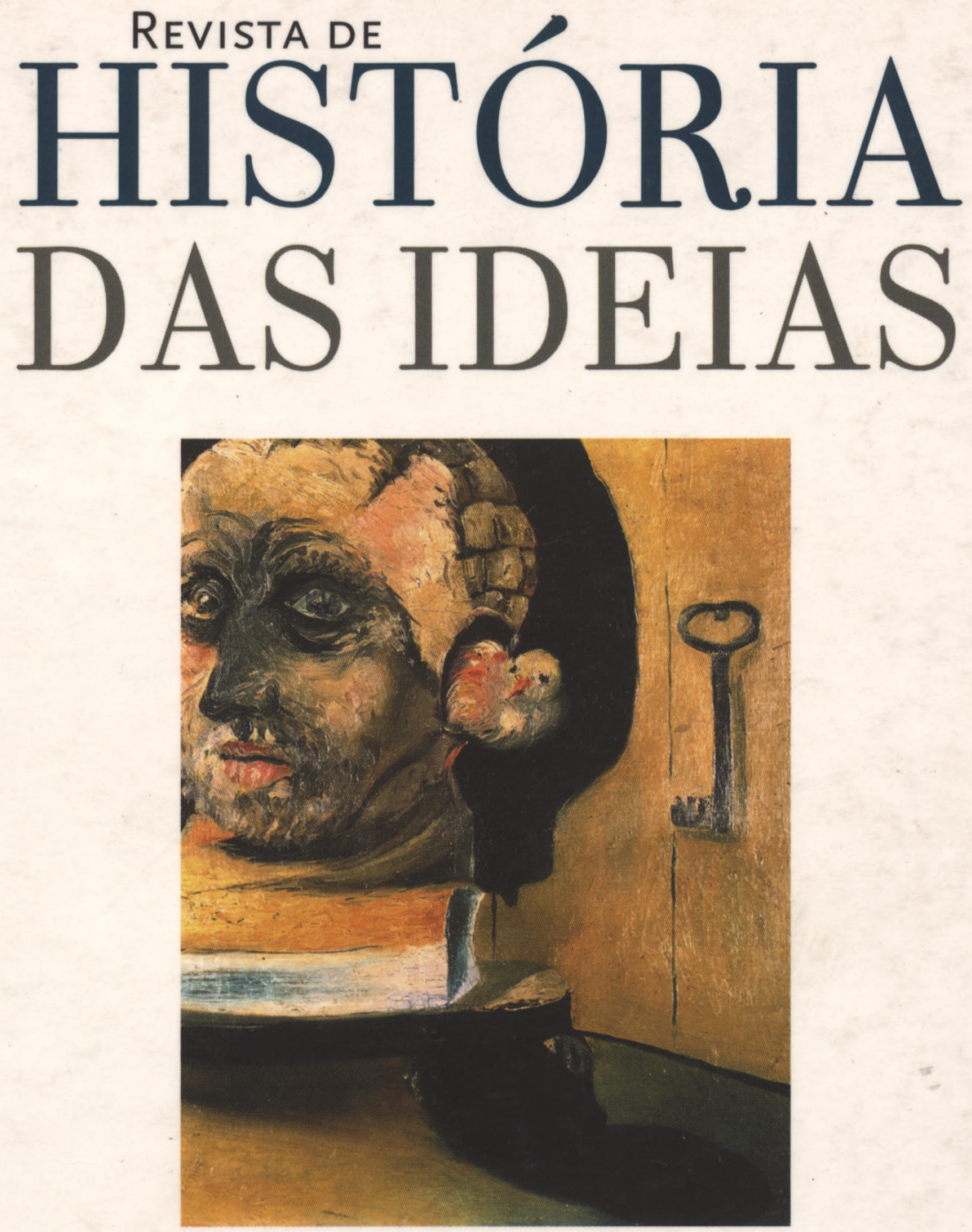

OS INTELECTUAIS E OS PODERES

Volume 24, 2003

INSTITUTO DE HISTÓRIA E TEORIA DAS IDEIAS

Faculdade de Letras da Universidade de Coimbra 


\title{
FILOSOFÍA DE LA HISTORIA Y SOCIOLOGÍA DE LA RELIGIÓN Las posiciones de Max Weber ante la Historia Universal
}

\author{
A Ingo Uhlig \\ "La apertura de la Historia Universal hacia culturas diferentes a la europea \\ u occidental, la apertura de la historia humana hacia la historia de la naturaleza \\ y la apertura del discurso histórico hacia la alteridad, de modo que abandone el \\ principio de exclusión, pueden constituir las bases de una nueva ontología y \\ una nueva dinámica de la Historia Universal". \\ J. C. Bermejo Barrera, Historia Universal: crisis de una idea
}

I

La mera visión panorámica de los estudios de sociología de la religión de Max Weber, tal y como se materializa en los Gesammelte Aufsätze zur Religionssoziologie (GARS), parece ofrecer un cuadro semejante al que, a lo largo del tiempo, ha ofrecido la Historia Universal. En estos estudios, nuestro autor abarca diversos ámbitos geográficos, que comprenden buena parte del orbe ${ }^{(1)}$. Sin embargo, las relaciones entre la Sociología de

* Universidad Santiago de Compostela.

(1) Y si atendemos al proyecto original, o simplemente si atendemos a los apuntes hechos en el apartado de la Religionssoziologie que aparece en Wirtschaft 
la Religión $(R S)$ weberiana y la Historia Universal en sus formulaciones seculares parecen más de conflicto que de afinidad; hasta podría sostenerse que, en su $R S$, el propósito de nuestro autor es el de dar la vuelta a las asunciones fundamentales de la Historia Universal en sentido hegeliano $^{(2)}$. La $R S$ de Weber sería así, a un tiempo, un programa teórico y una tentativa práctica de respuesta a la Historia Universal, que socavarán los principios en los que ésta se sustenta.

En todo caso, a la hora de sondear la posición de Weber frente a la idea de la Historia Universal, habremos de tener en cuenta las dos interpretaciones más contrastadas al respecto: 1) la que sostiene que Weber niega la Historia Universal y 2) la que sostiene que Weber la asume.

1) La primera opción sería la defendida por Gaetano Calabrò ${ }^{(3)}$. Para Calabrò, si bien Weber, desde sus primeros trabajos se halla interesado por las cuestiones de Historia Universal nunca se identificará con la versión tradicional de la misma; menos aún con los presupuestos teológico-filosóficos que la cimentan (ver Calabrò, p. 109). Para su exposición, el autor italiano se basará principalmente en los escritos del Wissenschaftslehre ${ }^{(4)}$, donde Weber manifestaría su oposición a tres tipos de Historia Universal: a) la hegeliana, b) la rankeana y c) la positivista. a) En su ensayo sobre Roscher, Weber critica la idea de "progreso" o de "desarrollo" y se opone, con Roscher, a la pretensión de los filósofos de la historia de ver en ésta "y en los acontecimientos externos de la vida

und Gesellschaft [RS(WuG)], el espectro con el que hubimos de conformarnos, tras la muerte del autor, en el que se estudia el occidente capitalista (Protestantische Ethik $[P E])$, China (Konfuzianismus und Taoismus [KET]), India y grandes áreas de Asia (Hinduismus und Buddhismus [HEB]) o el mundo judío (Das Antike Judentum $[A J])$, se extendería también al mundo islámico o al cristiano ortodoxo.

(2) En opinión de W. Schluchter, Weber "se distanciaba [...] de Hegel y de Marx, que en último término interpretaban la historia siguiendo el hilo conductor de la Aufhebung, de la "reconciliación"; orientada la una teológicamente, la otra antropológicamente, pero ambas sobre la idea de la historia del mundo como historia de la salvación." (Wolfgang Schluchter, Religion und Lebensführung, vol. 1, Frankfurt, Suhrkamp, 1991, p. 106).

(3) Ver Gaetano Calabrò, "Il rifiuto della 'storia universale' e il politeismo dei valori", recogido en Pietro Rossi, (dir.) Max Weber e l'Analisi del Mondo Moderno, Turín, Einaudi, 1981.

(4) Ver Max Weber, Gesammelte Aufsätze zur Wissenschaftslehre (WL), Tübingen, Mohr-Siebeck, (7 a ed.) 1988. 
humana algo parecido a una 'teodicea', como la fórmula de Schiller de la Historia Universal como 'tribunal universal'". (WL, p. 33, nota 2). En época de Weber, este esquema de la Historia Universal sólo se mantenía en el marxismo. La idea de progreso es necesaria, para Weber, sólo cuando el destino de la humanidad pierde su fin religioso y surge la necesidad de atribuirle un sentido inmanente y, sin embargo, objetivo (ver $W L$, p. 33, nota 2). Para Calabrò, Weber ya no consideraba posible hablar de curso histórico ni de su "tendencia" a justificar la fe en determinados ideales 0 valores; el saber no puede ejercer una especie de aval de nuestra elección, de la cual hemos de asumir completamente la responsabilidad y los riesgos que entraña (ver Calabrò, p. 110). b) Ranke recelaba de la idea de progreso, pero lo hacía ante todo por su sesgo laico. Por ello, contrapondrá a la misma un desarrollo en el que la fe religiosa constituía el elemento principal. Frente a la construcción metafísica de la historia hegeliana, Ranke dirá que el objetivo de lo histórico es ceñirse a los hechos; su presupuesto será el de la objetividad y la imparcialidad de la ciencia histórica. Weber, no obstante, ve en esto el trasunto de una fe religiosa que no representaba ninguna alternativa seria al planteamiento hegeliano. Weber le acusará precisamente a Roscher de haber perdido la oportunidad de criticar a la crítica hegeliana que aparecía en El Capital de Marx. c) La tercera variante de la Historia Universal a la que se opone Weber es la presente en la sociología sistemática de Comte. Weber condena el "prejuicio naturalista" del positivismo y el empleo en el ámbito de las ciencias histórico-sociales de conexiones construidas mediante leyes del tipo de las físico-matemáticas (ver Calabrò, pp. 112-113).

Ya Simmel se oponía a tesis como las de Ranke, planteando la imposibilidad de sostener el criterio de la reproducción de la realidad pues no se puede ver la realidad desde todos los puntos de vista. Weber dirá que no puede estudiarse todo de todo, sino que habrá de seleccionarse con arreglo a valores. Es decir, la acumulación de datos empíricos ha de tener un límite y éste no puede ser trazado más que a través de la elección del campo orientado por nuestros "intereses cognoscitivos" y nuestras "ideas de valor". Para Weber, no se puede establecer a priori ninguna armonía ni subordinación jerárquica tras las diversas "ideas de valor"; ni es posible determinar un sistema de disciplina con conceptos que tengan el carácter de leyes, capaces de "dar forma" a la infinita falta de sentido del devenir del mundo. Weber se desmarcará de Rickert y el neokantismo para prefigurar la tesis del politeísmo de valores. Somos seres culturales y le 
damos un sentido al mundo. No se puede "enlatar la realidad" en unos conceptos. Los problemas culturales del hombre son siempre nuevos mientras que el ámbito del devenir histórico universal sigue fluido. Weber se opondrá a la Historia Universal como sistema concluso. Para él, renunciar a la Historia Universal significa renunciar a la presunción de convergencia tras el fin ético-religioso y la corriente infinita del devenir universal que en épocas precedentes estaba garantizada por la ética cristiana y por el derecho natural laico. La crítica de la realidad presente se configurará, por tanto, como una crítica del Cristianismo y de su compromiso con el mundo. Mediante sus estudios de sociología de la religión, Weber trazará un análisis comparativo que responde en el plano metodológico a los problemas de la disolución de las normas ético-religiosas absolutas y de la formalización de la ética racional y sus postulados que forman parte de lo que él mismo define como "Entzauberung der Welt" (desencantamiento del mundo; ver Calabrò, pp. 120-121).

2) Frente a lo expresado por Calabrò, tendríamos opiniones como la siguiente: "[...] en un cierto sentido, no sólo se le puede denominar a Max Weber como historiador de la cultura o historiador social sino Universalhistoriker (historiador dedicado a la Historia Universal)" (Wolfgang J. Mommsen, Max Weber. Gesellschaft, Politik und Geschichte, Frankfurt, Suhrkamp, 1982 [1 ${ }^{a}$ ed. 1974], p. 182). Si bien Wolfgang Mommsen mantendrá esta afirmación en obras posteriores, con el paso del tiempo se verá cada vez más obligado a matizarla. En todo caso, seguirá sosteniendo que la obra sociológica de Weber ha tenido tan gran significación hasta la actualidad debido a que está concebida con criterios histórico-universales (universalhistorisch). El concepto de Historia Universal será, para él, el hilo que une el trabajo sociológico de nuestro autor: el punto de partida de sus trabajos históricos y sociológicos a la vez que de sus escritos políticos. Sin embargo, descubrir la concepción de su Historia Universal a lo largo de todas sus obras es una tarea muy problemática. "El propio Max Weber no ha querido desarrollar una teoría material de la Historia Universal, aunque su trabajo [...] contendrá numerosos puntos de partida para ello"(5). Mommsen incidirá en varios aspectos: a) sostendrá que Weber rechaza un modelo sincrónico de la

(5) W. J. Mommsen, "Max Webers Begriff der Universalgeschichte", in Kocka, Jürgen, Max Weber, der Historiker, Göttingen, Vanderhoeck \& Ruprecht, 1986 (pp. 51-72), p. 52. 
Historia Universal en favor de sistemas de modelos idealtípicos, que le iban a permitir la interpretación de los procesos sociales relevantes mirando a puntos de vista amplios referentes a la "importancia cultural"; b) considerará que el método de la Historia Universal weberiana no responde exactamente a ninguna de las diferentes interpretaciones que se han ofrecido en la gran controversia sobre la interpretación de su obra sociológica y que no afectaría, en primera línea, tanto a sus trabajos empíricos como al método histórico-universal como tal. Dicha controversia estaría protagonizada, en primer lugar, por las tesis neoevolucionistas de Schluchter, quien en su Die Entwicklung des okzidentalen Rationalismus ${ }^{(6)}$ sostiene que la concepción del desarrollo histórico de Max Weber se podría reconstruir como un desarrollo inevitable o como un modelo escalonado (Stufenmodell). Para este autor, la sociología de Weber habría de verse como una amplia historia social de occidente que tiene como objeto la construcción de la civilización universal racionalista moderna, que se distingue de todas las otras culturas históricas conocidas mediante un sistema muy desarrollado de dominación del mundo a través de los medios de la ciencia racional. Así, los estudios de Historia Universal de Weber no serían idénticos a la historia del racionalismo occidental, pero tendrían las condiciones de la construcción de las formas racionales de la acción social; es decir, de una economía capitalista racional y de una cultura marcada de modo racional como objeto esencial, incluso después, y precisamente después, cuando tratan culturas y religiones universales como el Hinduismo, el Budismo o el Judaísmo Antiguo. Schluchter hará mucho hincapié en la cuestión de los intereses y las ideas (de la Einleitung) ${ }^{(7)}$, poniendo de

(6) Wolfgang Schluchter, Die Entwicklung des okzidentalen Rationalismus, Tübingen, Mohr-Siebeck, 1979.

(7) Por Einleitung, se entiende la introducción a la Wirtschaftsethik der Weltreligionen (WEWR. Ética Económica de las Religiones Universales), es decir, se sitúa en los GARS, entre la Protestantische Ethik (PE) y Konfuzianismus und Taoismus (KET). Uno de los enunciados más emblemáticos de la Einleitung es el conocido como el símil del guardagujas: "Intereses (materiales e ideales), no ideas, dominan directamente la acción de los hombres. Sin embargo, las 'imágenes del mundo', que son producidas por 'ideas', con muchísima frecuencia han definido, como guardagujas, las vías en las que empujaba a la acción la dinámica de los intereses." (Einleitung, p. 252; traducción de Enrique Gavilán (E.G.),[Sociología de la Religión, Madrid, Istmo, 1997] p. 342). 
relieve la relación causal doble de la acción humana, determinada por la imagen del mundo y por las convicciones económicas, de un lado, y del otro por el orden económico y social. En esto, se diferenciará Schluchter de la interpretación neoidealista de F. Tenbruck, para quien el papel fundamental en la obra de Weber lo juegan las ideas; y de W. Hennis, que considera ante todo el sesgo antropológico de los análisis históricouniversales de Weber. Según Mommsen, Weber no quedaría absorbido por ninguna de estas interpretaciones. No se sabe hasta qué punto son decisivos los factores ideales, pero nuestro autor no tendría, en ningún caso, una concepción idealista del cambio social; la suya sería más bien bipolar: por un lado, pondría el acento sobre las fuerzas impulsoras de la acción social y, por otro, sobre la determinación de los procesos sociales mediante estructuras sociales, ideales y económicas sólidamente afirmadas en las que está ligado el individuo y que preforman sus intereses materiales en el sentido de acomodación y conformidad. En una época tardía (1920) formulará esto Weber en el célebre pasaje de la Einleitung; c) La estructura del esbozo de Historia Universal de Weber no puede considerarse un esquema teórico de evolución unilineal. Weber ha sido considerado como el teórico del proceso de secularización, de progresiva racionalización y desencantamiento de la cultura occidental, ligado con la construcción de la ciencia racional moderna, del estado moderno burocrático, del capitalismo industrial como desarrollo irreversible y, en general, como profeta de la expansión de la civilización occidental moderna sobre todo el orbe y de la victoria del sistema industrial. Las opiniones que sostienen que la tesis de la racionalización de Weber es el punto central de su teoría avalan tales consideraciones. Por tanto, según esa visión, no sorprende que esa racionalización opere siempre como Leitmotiv de una reconstrucción lineal de la Historia Universal en el pensamiento de Weber y que la civilización occidental se vea como la meta del desarrollo de la Historia Universal. Esa opinión la mostrarían Abramowski y Tenbruck, sobre todo. Schluchter sería más cauteloso; éste no se decanta por una marcha inevitable y continua del acontecer humano y más bien propende a referirse a la sociología weberiana como una teoría del nacimiento de la civilización universal racionalista moderna resultado de muchos factores muy diversos, principalmente de los impulsos de racionalización que se dieron a través de las imágenes religiosas del mundo. Por lo demás, se deja representar esta problemática central en un sentido tanto positivo como negativo 
respecto del capitalismo. En opinión de Mommsen, sería inoportuno reducir el trabajo histórico-universal de Weber a un proceso que se construye en torno a los conceptos de carisma (Charisma), cotidianización (Veralltäglichung), racionalización (Rationalisierung) y burocratización. El propio Weber ha podido favorecer esta interpretación con su siempre repetida tesis de la particularidad de la civilización occidental en comparación con los grandes sistemas culturales de la Historia Universal. "La forma en la que Weber formula aquí (en la Vorbemerkung) su Fragestellung, le ha dado la ocasión a Schluchter, entre otros, de concluir que en Max Weber 'no existiría una mera gradación superior del racionalismo occidental moderno dependiente del punto de partida, desde la perspectiva de las ciencias de la realidad, sino también una valoración del mismo abiertamente superior desde el lado de la filosofía del valor frente a los otros racionalismos'", (Mommsen, 1986, p. 62). El hecho de que Weber diga que los fenómenos culturales que se dan en occidente hayan tenido una importancia y una validez universal supondría que la cultura racional occidental estaría llamada a dominar el mundo. Aunque Weber reconoce que en el centro de su interés histórico-universal se encuentra el futuro de la cultura occidental, para Mommsen los estudios weberianos de historia social y económica no son sólo un programa de contraste para verificar y precisar su teoría del surgimiento del capitalismo moderno. Según este autor, Weber no quería sencillamente sobrepujar la historiografía mediante el desarrollo de un esquema evolucionista de la historia de la civilización occidental o menos aún de la Historia Universal en general. Nuestro autor se encontraría aún bajo una fuerte influencia de la literatura teórica evolucionista de fines del s. XIX, pero se esforzaba por liberarse de las teorías jerarquizadas (Stufentheorien) y de los modelos de desarrollo que eran corrientes allí (como se puede ver en su apasionado artículo sobre Stammler, ver WL, p. 291 ss.), pero también por mostrar su rechazo sin compromiso de la historia cultural de Lamprecht (ver Choi, Ho-Keun, Max Weber und der Historismus: Max Webers Verhältnis zur historischen Schule der Nationalökonomie und zu den zeitgenössischen deutschen Historikern, Bielefeld, Waltrop-Spenner, 2000, p. 115 ss.). La sociología histórico-universal de Weber no puede ser calificada de evolucionista ni se puede decir que refleje un esquema unilineal del desarrollo histórico universal cuya meta es la civilización occidental moderna y racionalista. Según Mommsen, denominar, como hacía Schluchter, a la de Weber una "historia social de 
occidente" es problemático en dos sentidos. De un lado, su obra no se concentra en el análisis de la historia de la cultura occidental sino que se ocupaba también de una parte considerable de fenómenos extraeuropeos. De otro lado, Max Weber se limitaba a sí mismo, y de forma muy consciente, a la reconstrucción sociológica y a la interpretación de determinados segmentos significativos del desarrollo histórico. Habría más bien que hablar de una pluralidad de "historias sociales". Weber pretendía representar, con la ayuda de ideales-tipo, no la totalidad de la realidad histórica sino segmentos significativos del desarrollo histórico universal, cada uno de los cuales contaba con una dinámica propia. Según Mommsen, si bien los viejos trabajos weberianos sobre la historia agraria y social, sobre el nacimiento del capitalismo o sobre la ciudad, entre otros, se pueden considerar tratados historiográficos a la vez que teóricos que siguen un esquema evolucionista, en las últimas partes de la Sociología de la Religión, empezando por la Zchwischenbetrachtung ${ }^{(8)}$ y acabando por el Soziologische Kategorienlehre ${ }^{(9)}$. Weber se ha zafado de cualquier concepción evolucionista de la Historia Universal que proporciona una tan engañosa impresión de unilinearidad y de determinación teleológica ${ }^{(10)}$. En este momento, Weber hablará de una racionalidad formal y una racionalidad material. La primera significaba una acción zweckrational en condiciones de adaptación a las relaciones dadas previamente; la última, la racionalización del modo de vida a la luz de ciertos valores últimos (Wertrationalität) ${ }^{(11)}$. La racionalización, por tanto, se habría dado

(8) Consideración intermedia, escrito que aparece en los GARS entre KET e Hinduismus und Buddhismus (HEB) y que lleva como subtítulo: "Theorie der Stufen und Richtungen religiöser Weltablehnung" ("Teoría de los grados y direcciones del rechazo religioso del mundo"), texto que para algunos autores viene a ser una especie de teoría weberiana de la cultura (ver por ejemplo, Charles Turner, Modernity and Politics in the Work of Max Weber, Londres, Routledge, 1992).

(9) Apartado de $W u G$, compuesto por los Soziologische Grundbegriffe, por las Soziologische Grundkategorien des Wirtschaftens, por Die drei Typen der Herrschaft y, finalmente por Stände und Klassen.

(10) Es importante no perder esto de vista pues ayuda a rebatir de partida algunas insensateces que se vienen escribiendo sobre Weber en los últimos tiempos (ver, por ejemplo, J.M. Blaut, Eight Eurocentric Historians, New York, The Guilford Press, 2000).

(11) Weber dividiría la acción social en cuatro tipos: 1) zweckrational (racional con arreglo a fines), donde el individuo valora racionalmente las consecuencias probables de un determinado acto y pondera la efectividad relativa de los posibles 
en los distintos ámbitos de la vida, con la mayor variedad de formas, en todos los círculos culturales. Será además crucial saber qué esferas y en qué dirección fueron racionalizadas. Así, existirán muchas posibilidades de racionalización. La particularidad de la racionalización occidental ya no la vería Max Weber en la progresiva racionalización de todos los ámbitos de la vida sino más en una forma de racionalización, de la mayor importancia cultural; a saber, la acumulación progresiva de racionalidad "formal" (es decir, "técnica"). Según Mommsen, por todo ello, "racionalidad" y "racionalización", a causa de sus múltiples significados, no serán ya conceptos claves que valgan para una reconstrucción idealtípica de segmentos del desarrollo histórico, por no hablar ya del círculo cultural occidental en su totalidad. Con la diferenciación entre los conceptos de racionalidad "material" y "formal", el concepto del proceso de desarrollo occidental sufrirá modificaciones; a saber, una relativización del teorema de la racionalización que les había servido a los primeros estudios de Historia Universal weberianos (aún poco reflexionados) al menos como clara línea a seguir. Ahora el camino estaba expedito para una nueva concepción comparativa de la Historia Universal; es decir, la historia como esencia de una pluralidad de procesos de racionalización en competencia.

Pese a la aparente oposición de ambos autores, sus posiciones no estarían tan distanciadas. En buena medida, no son más que dos formas opuestas de expresar lo mismo. Es más, nuestra posición se encuentra acorde con ambas. Por un lado, Weber rechaza la Filosofía de la Historia; pero, por otro, nuestro autor muestra el mayor interés por las cuestiones de Historia Universal y así lo plasmará en su RS. ¿A dónde nos lleva todo esto? Sin duda, a convenir que la Sociología de la Religión weberiana,

medios para conseguir un fin; 2) wertrational (racional con arreglo a valores), donde el individuo sólo tiene en cuenta los valores o ideas que le asisten y no tiene en cuenta otras consideraciones; 3 ) afectiva, donde el individuo lleva a cabo su acción sin contar con un ideal definido y dominado por componentes emotivos; y 4) tradicional, donde el individuo lleva a cabo su acción bajo el influjo de la costumbre y el hábito (ver Anthony Giddens, El Capitalismo y la Moderna Teoría Social, traducción de Aurelio Boix Duch, Barcelona, Labor, 1988, pp. 253-254). 
en su conjunto, es una respuesta radical a los planteamientos seculares de la Historia Universal y, por ende, un cuestionamiento profundo de las premisas básicas de la Filosofía de la Historia clásica. Weber es historiador universal a base de hacer estallar el corsé de la filosofía de ésta y de redefinirla a partir de nuevos presupuestos teóricos.

Ahora bien, tanto Calabrò como Mommsen (quién sabe si por su filiación sociológica) tienden a estudiar la cuestión sólo desde el análisis de Weber y dejan de lado la reflexión esencial sobre la naturaleza y los elementos constitutivos de la Historia Universal. No se trata de que no los contemplen o de que no se refieran a ellos sino, más bien, de que el lector difícilmente podrá ver la distancia prudencial que toma Weber respecto de las formulaciones clásicas de la Historia Universal puesto que los rasgos de ésta no aparecen definidos por ningún sitio. Sin conocer con precisión meridiana los rasgos de esa Historia Universal difícilmente podremos calibrar la dimensión auténtica de la respuesta weberiana a la misma ni, por ende, la trascendencia de la teorización weberiana como contramodelo al discurso histórico imperante (antes y después de él). Por un lado, Calabrò parece ante todo interesado en empujar a Weber fuera de los territorios de la historia y, si se centra en la $W L$, lo hace para mostrar el hueco abierto entre Weber y el historicismo. El recurso a la $W L$ es pertinente pero no suficiente. Como venimos señalando, hablar sobre la posición de Weber respecto a la Historia Universal implica tratar a fondo su RS. Eso es a lo que se dedica Mommsen, el cual, al margen de las apariencias, se mueve en un terreno muy difuso en el que, su posición excesivamente pegada a los planteamientos de nuestro autor, hace que se pierda el referente frente al cuál éste escribe y el propio alcance de su mirada. No obstante, Mommsen se mueve en la frontera misma del Weber historiador, algo que en el momento en el que él escribe no deja de ser problemático. Porque, al margen de otras consideraciones y de la importancia (indiscutible) de la obra de Weber para otras disciplinas, la relación entre la Religionssoziologie y la Historia Universal es un tema de teoría de la historia y las soluciones del autor son cotas teóricas de una altura desconocida por otros autores de su época, acalladas en el tiempo por diversas circunstancias en las que aquí no vamos a entrar. 


\section{II}

¿Cuáles son los fundamentos sobre los que se asienta la Historia Universal $^{(12)}$ ? Para hablar de ello, primero habría que empezar diciendo que la idea de la Historia Universal tiene, a su vez, una historia que se puede rastrear desde la Grecia antigua hasta la actualidad (a través de la cual se ha ido conformando su carácter) y cuenta con una serie de elementos esenciales que la constituyen. Según Bermejo Barrera, Heródoto reúne buena parte de los ingredientes necesarios para formular una Historia Universal, aunque en él, tal posibilidad se va a ver abortada. Este autor partía de una situación idónea para poder pensar la Historia Universal: las Guerras Médicas, en las que el mundo griego se enfrenta a un imperio "mundial", el persa. Ahí encontraríamos la primera premisa de la Historia Universal: la existencia de pueblos, ciudades o reinos distintos; es decir, la heterogeneidad. "Pero partiendo de lo heterogéneo no podría formularse dicha Historia, ya que la heterogeneidad debe superarse mediante un elemento que le imprima un sello de homogeneidad. Y en el caso de formaciones políticas divergentes, dicha homogeneidad sólo es posible si es impuesta, en nuestro caso por la conquista, es decir, si se dan las condiciones requeridas para el nacimiento de un imperio." (Bermejo, 1994, p. 222). Será también, en el ámbito de este imperio persa, donde se formulen las profecías del "Libro de Daniel", que con su teoría de la sucesión de los imperios se convierte en una fuente de la Historia Universal. La labor de Heródoto, por tanto, tendrá una doble vertiente, según Bermejo: por un lado, analizará al pueblo persa en su heterogeneidad (hasta el punto de convertirse en uno de los padres de la etnografía), pero, por el otro, ofrecerá ese diversidad como "alteridad" del mundo helénico. O sea, los pueblos que se hallan bajo el dominio persa se caracterizan por un rasgo básico que les unifica: "no son griegos", son "otros"(13). Por ello, "el tipo de comprensión que se logra se parece bastante a un juego de espejos en el que [...] el otro

(12) Un autor que ha dedicadosus esfuerzos a responder a esta pregunta es J.C. Bermejo Barrera, sintetizados en su artículo "Historia Universal: crisis de una idea", recogido como capítulo undécimo en Entre Historia y Filosofia, Akal, Madrid, 1994 (pp. 217-250).

(13) Bermejo señala, al mismo tiempo que, por ejemplo, para Heródoto sólo los griegos tienen ideas morales; el resto de los pueblos sólo pueden reflejarlas o refractarlas. La historia sólo puede escribirse a partir de sus valores y se convertirá en Magistra Vitae. 
aparece siempre conceptualizado como una imagen directa o inversa del yo o del nosotros." (Bermejo, 1994, p. 222). Heródoto definirá su ontología de los acontecimientos históricos: "una ontología en la que los hechos de armas que dan sentido a sus libros se enmarcan en un contexto más amplio: el de la confrontación con el bárbaro. Dicha ontología está caracterizada por una dinámica, que explica y da sentido a los acontecimientos, y que nos permite comprender por qué los bárbaros van a ser derrotados por los griegos. Y dicha dinámica va asociada a una axiología, a un sistema de valores. Si los griegos derrotan a los bárbaros es porque su forma de gobierno es mejor que la de éstos, y porque, por lo tanto, el griego es moralmente superior al bárbaro en sus usos, nómoi." (Bermejo, 1994, p. 223). Si Heródoto no formula propiamente una Historia Universal es porque se mueve en el ámbito de la sincronía y porque pese a formular esa ontología, esa dinámica y esa axiología en la historia, aún no es capaz de formular todavía plenamente la idea de Historia Universal porque en su dinámica la subordinación de pueblos y culturas no se encuentra al servicio de la consecución de un fin.

Tucídides dará un paso adelante. Este autor se dedicará a narrar una guerra civil entre griegos: la del Peloponeso. Su ontología será más reducida que la de Heródoto, pues sólo se dedicará a lo político, pero intentará hacerlo contrastando versiones, tratando de ser imparcial y crítico (de ahí que haya sido "ejemplo de historiadores"). Por ser su tema una guerra entre griegos, su relato carecerá de una etnología pero sí que contará con una antropología, al reflexionar sobre la naturaleza humana. Este autor trata de dar cuenta de los motivos de las acciones de los protagonistas, calificándolas de racionales y de irracionales; naturalmente a partir del establecimiento de lo que sea racional o irracional, normal o patológico, justo o injusto, según su criterio. Los presupuestos de esas diferenciaciones partirán de una moral determinada, asimilable a la herodótea. A causa del tema de sus escritos, Tucídides no puede ser considerado como un modelo de historiador universal; ahora bien, su antropología si que va a contribuir al desarrollo de la Historia Universal, en la que la identidad del individuo occidental, del ciudadano, y a partir de ella, de la nación y del estado serán prioritarias. Con Polibio, la construcción de la Historia Universal dará un gran paso adelante. Este autor grecorromano hará de Roma la unidad política capaz de integrar lo heterogéneo en un molde homogéneo, dando así unidad y sentido al curso histórico. En Polibio, pueblos heterogéneos se ven 
sometidos a un poder unificador y homogéneo. La constitución romana, que aúna las virtudes de la monarquía, aristocracia y democracia, es el resultado final de la evolución de las constituciones en el tiempo; con ello tendríamos un claro proceso de perfectibilidad. De este modo, la historia, que describe la forma en que los diversos pueblos del orbe pasan necesariamente a depender del poder romano superior, va a convertirse, en sí misma, en un argumento moral más. La percepción de ese proceso escalonado, va a perderse en historiadores como Tito Livio, cuya concepción histórica es más lineal, de forma que en su $A b$ Urbe Condita, Roma aparece como una identidad política y cultural única y completa desde los orígenes hasta su época. Sin embargo, la idea del estado universal de estos historiadores latinos va a permitir a los primitivos historiadores cristianos como San Agustín u Orosio formular una nueva Historia Universal a partir de la tradición cristiana. En Orosio, por ejemplo, el Imperio Romano será la culminación del proceso histórico, que no deja de ser un plan divino para preparar la llegada de Cristo al mundo y facilitar, gracias a la unidad política, la difusión del Cristianismo. Una vez que reconozca al Cristianismo como religión oficial, el Imperio Romano estará destinado a perpetuarse como única organización política posible. Posteriormente, con la fragmentación política que se dio tras el Imperio Romano, apenas podrá darse una Historia Universalista; será la historia la que desarrolle una idea de la historia eclesiástica asimilable, en competencia con la historia profana. En la Edad Media, la historia funcionará como una disciplina auxiliar de otras; por su carácter de saber de lo singular, quedará al margen de la filosofía y del conocimiento de lo universal, único considerado válido. Ambas circunstancias contribuyeron a su relegamiento. La historia en la Edad Media será un conjunto de crónicas locales o regionales que no aportarán demasiado a la Historia Universal (vinculada siempre a la vieja idea de Imperio y a la teología de la historia). Desde el Renacimiento, el cultivo de la historia será básicamente formal y retórico, si bien a partir del s. XVI irá considerándose que la misión del historiador ha de ser ante todo la de mantener la independencia de juicio, esbozándose la profesionalización de la misma, que sólo culminará en el s. XIX, y la separación definitiva respecto de la teología y la retórica. Se pretende que la que hable sea la "Razón"; de este modo se irá fraguando el método histórico. En 1681, Bossuet publicará su Discurso sobre la Historia Universal, que si bien no cuenta con demasiados elementos originales respecto de 
la concepción cristiana antigua, sí que imprime mayor vigor político a la idea de Historia Universal, pues será a partir de ella como intentará fundamentar el orden político y asentar la autoridad del príncipe. A partir de Bossuet se dará un doble proceso de liberación dentro de la Historia Universal: 1) ésta irá perdiendo las cadenas de la teología (con Voltaire, por ejemplo) y 2) saldrá de la exclusiva enseñanza de los príncipes extendiéndose a toda la sociedad.

La idea de la Historia Universal, tal y como la conocemos hoy, va a surgir del magma que dio origen a las historiografías nacionales y a la profesionalización de la historia, con todo su aparato institucional de creación de cátedras, archivos, museos, etc. Frente a la Historia Universal que se centraba bien en una forma política del pasado como el Imperio Romano bien en la Iglesia o la tradición católica, la Historia Universal del s. XIX partirá de dos elementos principales: 1) los estados nacionales y 2) el laicismo. Puede parecer una contradicción el hecho de que sean los estados nacionales los que den cobertura a una Historia Universal; sin embargo, tal contradicción se disipa cuando se aprecia cómo la nación concreta, se convierte a través de la historia en la medida moral, humana y política de las cosas, y necesita de una Historia Universal que permita mostrar el inmenso valor de la misma en comparación. La Historia Universal se concebirá por tanto a la medida de Europa; es decir, a la medida de cada una de las naciones europeas. A pesar de los matices que tengan los pensamientos de autores como Kant, Herder, Hegel, Michelet o Ranke, todos ellos comparten una concepción común de la Historia Universal. Dicha concepción deja de lado el problema de los orígenes o se refiere a él tan sólo de forma especulativa (hay que pensar que la Arqueología, la Prehistoria y la teoría de la evolución que permita acceder a los primeros momentos de la vida humana sólo surgirán a finales del s. XIX). Por lo tanto "se le fija un comienzo a la Historia, ya sea a través de un contrato ficticio que nunca existió, pero sin el que la Historia y la sociedad no serían comprensibles, o bien marcando un comienzo, como en Hegel, en la aparición de la escritura, en tanto que el registro escrito supone la aparición de la conciencia, y en cuanto que no puede haber Historia sin ella." (Bermejo, 1994, p. 232). De esta forma, para ellos, los seres humanos anteriores a la escritura habrían quedado al margen de la historia porque no habrían aportado nada. Como ya se ha señalado, sólo la aparición de la Prehistoria como disciplina, empezará a sacarlos del olvido. 
Uno de los pronunciamientos más emblemáticos de la Historia Universal es el de que la Historia comienza en Oriente ${ }^{(14)}$, pero éste pronto va a quedar al margen de la misma porque se quedó estancado en un momento de su evolución, en el que seguirá hasta que vuelva a reencontrarse de nuevo con Europa. "Es partiendo del Próximo Oriente Antiguo, de Egipto y Mesopotamia, como podemos comenzar a comprender la evolución histórica, entendida como una sucesión de formas políticas, como una sucesión de constituciones y como la crónica de las fases de desarrollo del Espíritu hegeliano. En el Próximo Oriente, nacen las primeras formas políticas estables, los primeros imperios y unas formas de cultura letrada, así como las artes figurativas y monumentales. Tenemos en él, pues, las bases de lo que denominamos civilización. Pero estas formas políticas están desequilibradas porque en ellas gobierna un déspota, un monarca o una clase sacerdotal y de escribas que mantiene una situación de estancamiento cultural con el fin de conservar sus privilegios. Será pues necesario dar paso a otras formas culturales, a las que se harán derivar del Oriente, como en el caso de la cultura griega en las teorías panbabilónicas o egiptizantes, que retomen de él lo mejor de su legado: su religión, sus ciencias, sus artes, pero que den paso a nuevas formas políticas en las que el despotismo oriental pase a ser sustituido por nuevas formas de gobierno aristocráticas o democráticas. Con ello, nos situaremos ya en Grecia." (Bermejo, 1994, p. 233). Grecia será asumida por las historiografías nacionales europeas como punto de referencia fundamental; Francia con su inspiración revolucionaria e Inglaterra con su talante liberal valorarán la tradición democrática helena; Alemania se identificará más con la tradición aristocrática espartana. Roma universalizará lo griego y ofrecerá un gobierno estable capaz de integrar a muchos pueblos diferentes. El mundo judío presentará también una notable función histórica hasta la llegada del Mesías. "Así, de este modo, con la fusión de lo mejor del judaísmo y del helenismo, unido al legado del Imperio Romano, recogido por la administración eclesiástica, tendremos las bases de la civilización europea y de sus naciones, que se irán fraguando, como sus lenguas, a través de la Edad Media." (Bermejo, 1994, p. 233). Pese al aparente retroceso general en la Edad Media, se operó en ésta un proceso muy satisfactorio a los ojos de las historiogra-

(14) No hay más que acudir a obras como las de J. G. Herder o F. Schlegel para comprobarlo. 
fías del s. XIX, la ruptura con la excesiva homogeneidad del Imperio Romano y la vuelta a una diversidad, en la que no obstante serán compatibles con una religión y cultura comunes. La Historia Universal arrostrará siempre esa tensión dialéctica entre unidad y diversidad. El Renacimiento supondrá un reencuentro con los orígenes clásicos, al igual que la Reforma y la Contrarreforma serán un intento de volver a conectar con las primitivas comunidades cristianas. Esta vuelta a los orígenes reforzará a las culturas nacionales, que poco a poco irán cultivando sus lenguas frente al latín e irán fundando iglesias nacionales o reafirmando la peculiaridad de cada iglesia dentro del catolicismo. Las naciones europeas se constituirán en la Edad Moderna y pasarán a ser estados-nación en el XIX, a partir de la Revolución Francesa, cuyos valores (derechos del hombre, constitucionalismo, liberalismo y democracia) adquirirán la máxima universalidad (por lo que Michelet acabó identificando la Historia Universal con la de Francia). De este modo, para la Historia Universal, la ontología del hombre será que éste es un animal político que se identifica con el ciudadano, excluyendo a la mujer y a todo lo que no sea actividad política, militar o gubernamental. Los valores de referencia seguirán siendo los definidos por una religión, el Cristianismo, y por su tradición cultural (derivada de la tradición clásica). Marx y Engels, con su análisis del capitalismo y su filosofía de la historia, se enfrentaron a esta idea europea de Historia Universal con la pretensión de ofrecer al mundo y a la historia una concepción alternativa. Sin embargo, la refutación de la idea de la Historia Universal no es posible, pues al ser muy general "puede ser compatible con la realidad mediante diferentes lecturas de los hechos. Las ideas de la razón histórica, como las concepciones del mundo, no son no refutables ni discutibles, se admiten o no y se las asume a partir de un sistema de valores." (Bermejo, 1994, p. 235). En el caso del marxismo, dichos valores son laicos y su teoría histórica y filosófica está ligada al compromiso; elemento éste que hace más vulnerable de lo normal a la idea marxista de la Historia Universal. En el momento en el que caigan las ideas y las formaciones políticas que la sostienen, la Historia Universal marxista entra en barrena.

Para Bermejo Barrera, la Historia Universal se halla en crisis en todas sus formulaciones. No obstante, "[...] la existencia de una crisis en la idea de Historia Universal no implica la detención de la actividad historiográfica. En primer lugar, porque gran parte del trabajo historiográfico 
es inmune a ella. Así, por ejemplo, la publicación y recolección de fuentes, la edición de corpora y la sistematización de las mismas; o bien los estudios monográficos, locales o regionales, o el análisis de infinidad de problemas históricos concretos." (Bermejo, 1994, p. 236). De todos modos, la existencia de la crisis de la Historia Universal no se trata, como pueda parecer de un fenómeno reciente, manifestado a través de multitud de nuevas concepciones globales de la historia, más o menos coherentes y más o menos incompatibles con las existentes, como la historia feminista de la mujer, la ecológica, la de la vida privada, etc., que responden a una fragmentación de la ontología de los objetos históricos. Esta crisis es percibida ya desde principios de siglo. Precisamente, la $R S$ de Max Weber supone un cuestionamiento de la Historia Universal difícil de soslayar, aunque las derivas del siglo $X X$, hayan pasado de largo sin sopesar esta cuestión de forma conveniente. En ella, se opera una auténtica superación de todos los elementos que, una vez más según la teorización bermejiana, constituyen la idea clásica de la Historia Universal; a saber: 1) la unidimensionalidad; 2) el carácter lineal; 3) el etnocentrismo; 4) el carácter sexista; 5) la exclusión; y 6) el carácter providencial.

1) La Historia Universal del s. XIX es unidimensional en tanto en cuanto contempla sólo una dimensión política. Ya Marx, tratará de añadir la dimensión socioeconómica y Burckhardt, la religiosa y la cultural. En el siglo XX, la Historia Universal adquirirá muchas dimensiones lo que equivaldrá a perder sus dimensiones; este fenómeno se dará especialmente a partir de los años 40 en Francia, con la Escuela de los Annales, que buscará obsesivamente nuevos objetos de estudio y que se esforzará en todo momento por buscar la novedad. Esta Historia en migajas, como la denomina F. Dosse ${ }^{(15)}$, pone de manifiesto la crisis de la idea de la Historia Universal, a causa de la pérdida de cualquier ontología.

2) Si hay algo que defina a la Historia Universal es su carácter lineal, su conformación como teleología que se plasma en la noción de "progreso". El proceso histórico se estudiará con arreglo a su finalidad, ajustando y seleccionando los hechos a describir en relación con él. Asociada a la noción de progreso se encuentra la idea de subordinación de unas épocas a otras o de unas culturas a otras; unas harán de antece-

(15) Consultar, La Historia en Migajas, trad. de Francesc Morató i Pastor, Valencia, Edicions Alfons El Magnànim, 1988. 
dentes necesarios de aquéllas que están llamadas a ser superiores. Esos antecedentes quedarán subordinados a las "fases superiores de desarrollo". "En un proceso de causación lineal, la causa es anterior a la consecuencia tanto cronológica como ontológicamente, puesto que lo consecuente no puede existir sin el antecedente. En Historia, esto también es así, pero dándose la particularidad de que la consecuencia asume la causa, la integra en su ser y la supera, otorgándole así su sentido." (Bermejo, 1994, p. 238). La misma sucesión se percibe en la sucesión dialéctica de los modos de producción que se encaminan hacia la sociedad comunista. La Historia Universal sólo puede adquirir un sentido cuando se ha operado un proceso de dominación de una cultura por parte de otra.

3) Ligada a los elementos anteriores de subordinación y necesidad histórica se encuentra el carácter etnocéntrico de la Historia Universal. El Antiguo Oriente, Grecia y Roma adquirirán su verdadero sentido gracias a que se les entiende como eslabones en la cadena de progreso que lleva hasta la civilización europea contemporánea. "Quedan en el transcurso histórico numerosos pueblos marginales, y hay también pueblos que ni siquiera han llegado a entrar en la Historia. La reconciliación de la Historia con todos ellos sólo tendrá lugar a partir de la expansión europea, cuando, mediante la colonización, dichos pueblos se integren y asuman los valores de la civilización europea, que serían superiores a los restantes no debido a ningún tipo de prejuicio sino debido a su mayor grado de universalidad." (Bermejo, 1994, p. 239). Evidentemente, tal colonización supondrá una dominación que imponga tales valores y la historia será uno de los pilares ideológicos en ese proceso, pues proporcionará los argumentos de esa dominación, en la época en la que se estaba materializando la expansión colonial ${ }^{(16)}$. El etnocentrismo no puede ser comprendido de modo aislado sino que forma un sistema con las características mencionadas y sólo tiene sentido si tenemos en cuenta que la historia adquiere su sentido "en el marco de los discursos socialmente compartidos y de los imaginarios sociales." (Bermejo, 1994, p. 240).

(16) Resultan muy interesantes las reflexiones de Bermejo Barrera sobre el papel de la escuela histórica del derecho a la hora de sustentar el derecho de una nación a dominar a otras, consagrando la diferencia entre pueblos y naciones (ver Bermejo, 1994, p. 239). 
4) La historia, además de justificar la confrontación política entre las naciones o el derecho de los pueblos a dominar o colonizar a otros, se dedicará a su vez a justificar todo aquello que está implícito, es decir, las estructuras sobre las que se asienta el orden social. Eso lo hace concediéndose un tipo de ontología, principalmente la de los sujetos históricos. Así, la Historia Universal se caracterizará también por su componente sexista. La Historia Universal será básicamente una historia de hombres porque la mujer estaba excluida de su ontología. Es por ello quizá que la mujer propone su propia historia como alternativa a la Historia Universal.

5) Ahora bien, la relegación absoluta de la mujer ha de entenderse como una parte del amplio discurso de exclusión que es la Historia Universal. Esta historia sirve al orden establecido, por tanto, habrá de excluir todo lo que constituya una amenaza a éste en uno u otro sentido. "Dicha exclusión se configura como una exclusión de temas de estudio. $\mathrm{Al}$ afirmar sus objetos de estudio, la Historia niega a todos los restantes, puesto que no admite que la construcción del objeto histórico sea contingente ni esté culturalmente condicionada. La Historia actúa en el reino de la necesidad. Los objetos históricos no sólo son así, deben serlo. Y su ser es excluyente. Sólo existe un mundo histórico, el único posible, y además de ser el único es necesariamente el mejor." (Bermejo, 1994, p. 241).

6) La Historia Universal asume como otro de sus elementos su carácter providencial. Ella refleja en sí la idea de que vivimos en el mejor de los mundos históricos posibles, donde todo cumple una función y es necesario. Dentro de ella parece manifestarse un plan oculto que conduce a lo mejor (la providencia de la historiografía cristiana, la astucia de la Razón de Hegel, las leyes de la historia del materialismo histórico... etc.). El marxismo salió al paso de ese "mundo feliz" resultante del proceso histórico y le contrapone la idea de un mundo en el que predomina la explotación, la injusticia y el mal. Para Bermejo, "[...] se puede afirmar que la idea de Historia Universal, tanto en su versión liberal como en su versión marxista ha entrado en crisis. Al sustituir la unidimensionalidad por la infinidad de dimensiones, al perder el carácter lineal y asumir la plurilinealidad, al no admitir de forma generalizada la idea de subordinación entre pueblos y épocas, al no aceptar una necesidad histórica omnipotente que acaba por justificar el orden mediante las estrategias de exclusión, esa vieja idea se nos ha quedado inservible. Sin embargo, no parece que surja otra que pueda sustituirla." (Bermejo, 1994, p. 242). 
Analizar el legado weberiano desde la perspectiva de la Historia Universal supone poner su pensamiento frente a estos planteamientos histórico-universales, que de manera tan sintética expone Bermejo. La RS weberiana nos permitirá calibrar hasta qué punto nuestro autor plantea una crítica de la Historia Universal en todos los frentes: a) desde su misma definición, dicha $R S$ se muestra pluridimensional, pues trata de desvelar las relaciones entre el mundo de las ideas (especialmente, las religiosas) y el mundo social y económico, sin dejar de lado el intelectual, el estético, el científico o el erótico ${ }^{(17)}$; b) la RS es ajena por completo a cualquier teleología, a cualquier idea de progreso lineal o de perfectibilidad de la Historia Universal. El "universo" de Weber está poblado de unidades que tienen una evolución particular, al margen del resto, según sus propias leyes ${ }^{(18)}$. Las diferentes Eigengesetzlichkeiten de los distintos ámbitos, llevarán no obstante a que se produzcan choques y superposiciones: la más significativa por sus dimensiones mundiales habría sido la protagonizada por el despliegue de la racionalidad surgida en occidente. No obstante, el pensamiento weberiano expresado en los argumentos teóricos de su $R S$ cuestiona el sentido de la modernidad, entendida ésta como el punto de llegada del aludido progreso; c) tanto la idea de hombre como la de mujer tienden a diluirse bastante en el relato weberiano; en todo caso, a buen seguro bajo la influencia poderosa de Marianne Weber (feminista militante) la $R S$ estará traspasada por una denuncia constante de la situación

(17) El texto paradigmático en el que Weber teoriza sobre esas esferas es el conocido como Zwischenbetrachtung (ver GARS I, pp. 536-573), situado entre KET y HEB.

${ }^{(18)}$ En opinión de nuestro autor, en contextos diferentes, un fenómeno aparentemente idéntico estará a menudo originado y desarrollado a partir de premisas particulares, a partir de una lógica propia (Eigengesetzlichkeit), que en la evolución posterior de sus atributos dará lugar a resultados prácticos muy diferentes y sólo comprensibles si, precisamente, se ha tratado de encontrar la lógica interna de su desarrollo. Dieter Conrad constata que el término Eigengesetzlichkeit (que, por cierto, muy a menudo aparece oculto en las traducciones) surgió en la época en la que Weber redactaba su $H \mathcal{E} B$ y lanza como hipótesis que es él quien lo acuña y lo introduce en el vocabulario alemán, a pesar de que nunca se arrogue su creación (ver Dieter Conrad, Max Weber's conception of Hindu Dharma as a paradigm, en D. Kantowsky (ed.) Recent Research on Max Weber's Studies of Hinduism, Munich, Weltforum Verlag, 1986, pp.169-192). 
subalterna de la mujer en casi todos los ámbitos estudiados ${ }^{(19)}$; d) el panorama de exclusión que se planteaba en la Historia Universal se ve diluido en la $R S$ de Weber. La propia concepción de la WEWR supone no sólo la

(19) Un ejemplo, entre muchos otros, de esto que decimos, lo encontramos sin salir de los estos de la Sociología de la Religión weberiana (ver $R S(W u G)$ pp. 297-298). En estas páginas, Weber hace un largo excurso sobre los niveles de exclusión de la mujer en las diferentes comunidades (religiosas), dejando traslucir un abierto sesgo "feminista". Las líneas principales de este excurso serían las siguientes: 1) La religiosidad de los desfavorecidos se interesaría por la igualdad de derechos de las mujeres; 2) serán más o menos admitidas en los cultos religiosos en relación al pacifismo relativo o a la militarización del mismo; 3) la existencia de sacerdotisas, adivinas o hechiceras (en suma, mujeres con carisma), no significa ni por asomo igualdad de las mujeres en el culto; 4) a la inversa, el que se sostenga la igualdad de principio en la relación con lo divino (como ocurre en el Cristianismo y en el Judaísmo; de forma menos rigurosa en el Islam y oficialmente en el Budismo) no es óbice para el monopolio absoluto masculino de la función sacerdotal y del poder de decisión en la congregación, puesto que sólo a los hombres se les considera cualificados; 5 ) la gran receptividad de las mujeres para la profecía religiosa (no militar o política) se pone de manifiesto en las relaciones libres y sin prejuicios de casi todos los profetas (Cristo, Buda e incluso Pitágoras) con mujeres; no obstante, con la Veralltäglichung (cotidianización, rutinización) posterior y la reglamentación de las relaciones de la congregación se contraatacará contra la religiosidad femenina (ejemplo de esto sería san Pablo); 6) las profecías políticas y militares (como el Islam) no sólo se dirigen a los hombres; 7) Allá donde domina la educación ascética guerrera (implicando el "renacimiento" del héroe), se considera a la mujer como carente del alma heroica superior y por ello es descalificada religiosamente: "La mujer queda completamente excluida de los cultos oficiales chinos, así como de los romanos y brahmánicos; incluso en época merovingia, sínodos cristianos pudieron poner en duda la igualdad del valor del alma de la mujer" (p. 298; E.G., p. 161); 8) Por el contrario, ciertos cultos específicos del Budismo, del Taoísmo o del Cristianismo antiguo, han extraído su fuerza propagandística de la colaboración e igualdad con las mujeres; también en los cultos dionisíacos, donde se alcanzaron unos niveles de emancipación de las convenciones totalmente insólitos, aunque poco después esa libertad se fue estilizando y quedándose en ceremonial, quedándose así constreñida a procesiones y actos festivos, perdiendo su relevancia práctica. (¿Podrá entenderse esto como una velada alusión a la liberación "orgiástica" de la que habría sido testigo nuestro autor en su tiempo, por ejemplo, a su paso por Ascona, luego sintetizada y limitada en las danzas rituales de Rudolf Laban? - ver Martin Green, Mountain of Truth. The Counterculture Begins. Ascona, 1900-1920, Londres, University Press of New England, 1986). "No puede decirse en absoluto que todas las religiones de 'amor 
marcha hacia el "Otro" no occidental sino también hacia el heterodoxo religioso, social o político buscando encontrar su posición y su papel dentro de cada una de las construcciones idealtípicas. Lo diferente pone en cuestión la posibilidad misma los modelos, socavándolos y matizándolos. En general, nuestro autor será poco amigo de la exclusión, incluso en su vida. Su oposición al antisemitismo será una buena prueba de ello ${ }^{(20)}$; e) en la $R S$ de Weber no se percibe ni un solo atisbo de providencialismo histórico. Su posición ambigua ante la modernidad le sitúa lejos de la creencia en que el nuestro sea el mejor de los mundos posibles o el resultado esperanzador de un progreso creíble ${ }^{(21)}$ : la $R S$ no cree ni en providencias ni en astucias de la razón ni en leyes de la historia tan sólo en el despliegue errante del destino particular al que llevan algunas ideas particulares.

Hemos dejado aposta para el final la crítica del etnocentrismo por el significado especial que tiene para nosotros. Frente a la Historia Universal, la $R S$ de Weber: 1) no ve a lo no-occidental como "Otro" pues

al hermano y al enemigo' alcancen esa posición por influencia de carácter feminista: por ejemplo la religiosidad india de la Ahimsa, rotundamente no. La influencia de las mujeres suele intensificar solamente los aspectos emocionales, de tipo histérico. Así ocurre en la India. Pero no es indiferente que la religiosidad de redención suela glorificar las virtudes no militares y antimilitares, como ha de ser natural para los estratos desfavorecidos y las mujeres." (p. 298; E.G., p. 162). En esta forma de situar a la mujer al lado de los esclavos y jornaleros, Weber se adelanta a las posiciones de Gayatri Spivak.

(20) Weber será uno de los pocos intelectuales alemanes a los que salve de la quema por antisemitismo un juez tan severo como Daniel J. Goldhagen (ver Daniel J. Goldhagen, Les bourreaux volontaires de Hitler. Les allemands ordinaires et l'Holocauste, tradución del inglés al francés de Pierre Martin, París, Seuil, 1997, p. 94).

(21) Al, para muchos, adalid teórico del capitalismo, se le soprenden a menudo inquietantes fragmentos que ponen seriamente en cuestión tal encasillamiento. Como muestra, un botón: "nadie sabe aún quién vivirá en el futuro en aquella carcasa [la de la sociedad capitalista] ni si al final de este desarrollo gigantesco aparecerán profetas completamente nuevos o habrá un poderoso renacimiento de viejos pensamientos o ideales, o (si no se da ninguna de esas dos cosas) si, por el contrario, se dará una petrificación mecanizada, disimulada por un modo espasmódico de darse importancia. Entonces, en efecto, podría llegar a ser verdad para los 'últimos hombres' (für die 'letzten Menschen') de este desarrollo cultural, el adagio: 'Especialistas sin cerebro, hedonistas sin corazón: esta nada se imagina haber llegado a un nivel de la humanidad jamás alcanzado'" (PE, GARS I, p. 204). 
el concepto de Eigengesetzlichkeit le devuelve a la historia su heterogeneidad. Weber rompe con la idea de "Otro" como inversa del "yo", y opone lo "eigenartig" (particular) a lo "andere" (otro). La RS estudia el despliegue de lo particular sin inscribirlo en ningún proceso universal unívoco ${ }^{(22)}$. Desde esta premisa, no se puede hacer Historia Universal al uso; 2 ) si bien Weber sí que contempla en su producción lo racional y lo irracional, el uso que hace de ambos términos no es, en absoluto, sencillo $y$, por supuesto, no está asociado a la dicotomía: occidente (racional) oriente (irracional). La propia idea weberiana de "racionalidad" colma de matices lo que la Historia Universal había asumido de modo esencialista; 3) en la postura ante lo que se ha venido denominando como "Oriente" reside una de las variaciones más profundas de la aportación weberiana respecto de la Historia Universal. En primer lugar, frente a ésta, Weber no se dedica a situar a tal "Oriente" en los albores de la humanidad ni a tratarlo simplemente como un "momento originario" o subdesarrollado, que permanecerá estancado hasta su reencuentro con Occidente, sino que sus estudios de China o la India, por ejemplo, dibujan una perspectiva que se despliega desde el interior mismo de esos ámbitos, de forma que occidente sólo aparece como elemento de contraste ${ }^{(23)}$. Weber pretende resaltar lo rarísima que ha sido la evolución de occidente $\mathrm{y}$, para hacerlo, trata de mostrar la lógica manifiesta de las evoluciones particulares (Eigengesetzlichkeiten) de los diversos ámbitos. Es por ello, que nuestro autor no se queda en los "orígenes gloriosos" de oriente sino que sigue, en buena medida su evolución hasta la contemporaneidad, precisamente hasta ese encuentro con occidente; 4) la $R S$ de Weber

(22) Eso no es óbice para que el despliegue de la particularidad del Protestantismo ascético tenga, en su opinión, a través del capitalismo, un significado cultural universal; el mismo es un rasgo de su peculiaridad. No sorprende que sea precisamente esa vocación hacia lo universal la que dé origen a las teorías de progreso de la humanidad hacia lo mejor.

(23) Teniendo en cuenta que Weber escribe para un público occidental, la apoyatura en referencias a occidente están al servicio de la mejor comprensión de la exposición ("A es/no es como B") y de las búsquedas generales de su trabajo; a saber, percibir los parecidos y las diferencias, de un ámbito con respecto del resto. Resulta paradójico, pero a veces llega a darse el caso de que donde quizá se excede nuestro autor al desarrollar sus tipos es en la tendencia excesiva a la correspondencia entre ámbitos diferentes, lo que le llevará a ciertos errores de apreciación cuyo tratamiento excede los límites de este artículo. 
no puede servir como sustento a un discurso colonialista puesto que parte de una profunda sospecha respecto de la modernidad y puesto que no puede establecerse de forma racional que las culturas extraoccidentales sean intrínsecamente superiores o inferiores a la occidental ${ }^{(24)}$; el "científico" weberiano a lo más que puede llegar es a señalar las diferencias. En definitiva, por todo ello, Weber rompe con el prejuicio etnocentrista (europeocentrista), el más duradero y difícil de extirpar de la Historia Universal. El relato de la $R S$ podrá considerarse como claramente descentrado.

\section{III}

Con todo, la mejor forma de calibrar el alcance de la particular alternativa weberiana a la Historia Universal nos parece la de revisar su último escrito, la Vorbemerkung, en el que se establecen las bases que cimentan su trabajo ${ }^{(25)}$. La traducción "Introducción" o "Author's Introduction" no refleja su carácter auténtico ${ }^{(26)}$. Pese a que el autor nos refiere concisamente, en el mismo, las razones por las que ha recopilado los ensayos de la $P E$ y de la WEWR y el sentido que confiere a dichos textos, no parece ser ése su objetivo fundamental sino que se sitúa en un nivel superior de reflexión a la vez general y profunda sobre todo-lo que va a venir después. En la Vorbemerkung, Weber se dedicará a desarrollar las líneas básicas de sus consideraciones en torno a los fenómenos de

(24) ¿Cómo podría comparecerse una visión del discurso weberiano como etnocéntrico y colonialista con afirmaciones como la que incluimos a continuación? "La rigurosa estilización ceremoniosa y jerárquica de su modo de vida ha protegido a la cultura asiática de intentar, al modo occidental moderno, lo que justamente es propio del individuo de occidente y sólo de él, a diferencia de todos los demás, sacarse a sí mismo del pantano tirándose del pelo y construirse una 'personalidad' - un esfuerzo tan estéril como el intento de invención planificada de una forma artística propia, que quiere ser 'estilo'" (pp. 377-378; E.G., p. 439).

(25) No deja de resultar expresivo que el último texto que salió de la pluma de Weber lleve en sí la marca de la precedencia.

(26) Resultan más adecuadas las traducciones de Vorbemerkung como "Prefacio" (E. Gavilán, 1997) o como "Nota Previa" (J. Navarro Pérez, La ética protestante y el espíritu del capitalismo", Istmo, Madrid, 1998). 
racionalización, en torno a la peculiaridad del capitalismo occidental y al papel de las creencias religiosas en la aparición de la mentalidad económica. De este modo, sin embargo, resulta que los GARS como tal no tendrán un texto introductorio amplio y después de la Vorbemerkung aparecerá directamente la $P E$ (con las transformaciones correspondientes respecto de su edición original de 1904-1905) ${ }^{(27)}$. Tal vez haya sido la falta de una apertura más claramente introductoria (que el autor pudo haber llevado a cabo pero no consideró necesaria) lo que ha dejado el campo abierto a la discusión sobre los límites y el alcance de los GARS, sobre la relación de la primitiva $P E$ respecto de la $W E W R$, o sobre la inclusión selectiva de los escritos de la $R S(W u G)$ dentro de los GARS.

En todo caso, en la Vorbemerkung nos enfrentamos a uno de los textos más apasionantes y cruciales de su autor; así lo refiere, por ejemplo, Benjamin Nelson, que la incluye en la lista de los ensayos más reveladores y fecundos de Weber porque "nos ofrece ideas, que en otros lugares de su obra sólo habían aparecido de forma oblicua e intermitente, como caminos en los que él había de interpretar los significados del esfuerzo de toda su vida en el cénit de su carrera." (Nelson, p. 218) A su vez, para este mismo autor, la Vorbemerkung es quizá "la afirmación general más fuerte que nos ofrece Weber de su conciencia madura de que la realización de sus propósitos principales como sociólogo no era posible sin un compromiso definido con una perspectiva que él mismo llamaba histórico-universal [...]. Aquí Weber deja bien claro que estaba comprometido con la exploración de todos los elementos - tanto extraeconómicos como económicos - que habían cooperado para producir la transformación, única hasta entonces, de partes de la Europa occidental en la dirección de la racionalización, el racionalismo, la industrialización, la racionalidad, la modernidad, respecto a la organización de la conducta, la división del trabajo, la dirección de los negocios... las orientaciones al 'mundo' y a la 'religión', la consecución de la perfección. [...] Desgracia-

(27) Este hecho ha llevado a que se haya podido dar el caso de autores como Ehud Sprinzak que, con todo descuido, han referido la frase que inicia la Vorbemerkung como la que inicia la PE... (ver Benjamin Nelson, "Max Weber's 'Author's Introduction' (1920). A master clue to his main aims", en P. Hamilton, (ed.), Critical Assessments 1, Vol I, pp. 216-231, Londres, Routledge, 1991, pp. 216- 217). 
damente, estos estudios escaparon totalmente a la atención de sus historiadores críticos." (Nelson, p. 218) ${ }^{(28)}$.

¿Cuál es el contenido de la Vorbemerkung? ¿Por qué resulta uno de los textos más sugestivos de Max Weber? En éste escrito último de Max Weber, el autor, que se autodenomina indirectamente como un Sohn der modernen europäischen Kulturwelt (hijo del mundo cultural europeo), sombra sobre la que no puede saltar pero que apura hasta las heces, considerará que, como tal, la reflexión sobre los problemas de la Historia Universal le precipita de forma inevitable a una cuestión central: "¿Qué encadenamiento de circunstancias ha conducido a que justamente en occidente y sólo aquí aparecieran fenómenos culturales que - al menos como nos gusta representárnoslos - se encontraban en una línea de desarrollo de significado y validez universales?" (GARS I, p. 1; E.G., p. 313). El hijo del mundo cultural europeo se pregunta por qué justamente en occidente ( $y$ no en otro lugar) aparecieron fenómenos culturales que tendrían una trascendencia, un alcance, una importancia, un significado y una validez universales. El hijo del mundo cultural europeo quiere saber dónde reside la peculiaridad que hace de occidente, especialmente en ese cambio del siglo XIX al XX, el dominador incontestado del resto de los continentes, del resto de las culturas. Es decir, será Weber quién plantee la gran pregunta de la historia en la contemporaneidad: ¿Por qué occidente y no otro ámbito?

El término "occidente" tiene en nuestro autor una impronta netamente cultural. Occidente es "lo occidental", es decir, lo que ha germinado a partir de las semillas de la racionalidad occidental, ya se ubique en Inglaterra, Estados Unidos, Sudáfrica o Australia. "Occidente" (Okzident) es para Weber la denominación genérica de un tipo complejo de racionalización y precisamente en esta Vorbemerkung, el autor desplegará multitud de ejemplos en los que "occidente" se construye a sí mismo en contraste con lo no occidental; lanzará la mirada sobre lo que occidente considera como "Otro" para tratar de conocer lo que podría suponérsele

(28) Nelson insiste también en que, en ese momento intelectual postrero en el que está nuestro autor, a la hora de redactar su Vorbemerkung, éste se encuentra en plenitud intelectual, como lo demuestra el hecho de que sus referencias estuvieran perfectamente actualizadas. Algunas notas del "Prefacio" señalan obras de 1919 como la "Psychologie der Weltanschauungen" de Jaspers o la segunda edición de Der moderne Kapitalismus de Sombart, de 1916-1917, (p. 217). 
como "propio". Con ello, tratará de mostrar lo extraño y lo peculiar del desarrollo occidental. Para Weber no es que "lo nuestro" sea "lo normal" y lo otro "lo anormal" sino que más bien resulta que desde las perspectivas de otras culturas como la China o la India, la nuestra se muestra como una cultura en absoluto evidente, cuyos pasos evolutivos son todo menos necesarios en lo humano; menos aún, superiores. Lo que hace nuestro autor es, en esencia, dibujar los contornos de la diferencia. Ahora bien, será precisamente en este terreno donde se darán los mayores malentendidos, que provocarán que el pensamiento de Weber sea considerado como etnocéntrico: "Sólo en occidente hay 'ciencia' en el estadio de desarrollo que hoy consideramos 'válido'". (p. 1; E.G., p. 313). "Occidente" y sólo "occidente" ha desarrollado una "ciencia" que por mor de su dominio se muestra universalmente válida. Ahora bien, esa validez está sujeta al "hoy" y al "nosotros". Weber evita el papel de visionario y se limita a constatar lo que se considera válido para el momento presente. Por otro lado, señala que somos "nosotros" mismos los que concedemos validez a "lo que es nuestro", algo que no parece tan claro en el caso de los miembros de otros ámbitos culturales extraoccidentales. Esa validez, por tanto, no será el reflejo de ninguna superioridad occidental sino más bien de su peculiar racionalización. En India, en China, en Babilonia, en Egipto se desarrollaron también conocimientos empíricos, se reflexionó sobre los problemas del mundo y de la vida, existió una filosofía y una teología profunda y unos saberes y observaciones de carácter muy refinado... y pese a todo, en mayor o menor medida, diferentes a las que se dieron en occidente; para algunas, en occidente ni siquiera tenemos denominación asimilable. Así, según Weber, la astronomía babilónica carece de una fundamentación matemática; la geometría india, de la "prueba" racional; las ciencias indias de la naturaleza, del experimento racional y el laboratorio moderno. Sólo occidente conoce la química racional. La historiografía china carece "de la precisión tucidiana de los hechos"(29). Todas las doctrinas asiáticas sobre el Estado carecen de una organización sistemática y de conceptos racionales. El derecho extraoccidental carece de los rigurosos esquemas

(29) Este es un ejemplo extraordinario para mostrar cómo lo que en el "hoy" de Weber se consideraba como "racional", en nuestro hoy quizá ya no lo sea tanto. 
y formas de pensamiento jurídicos del derecho romano y del occidental formado en él. Algo similar ocurrirá para él en el ámbito estético y ahí se referirá muy especialmente a la particularidad de la música occidental: "Probablemente, el oído musical alcanza mayor finura en otros pueblos que entre nosotros hoy en día; en todo caso, su finura de oído no es inferior a la nuestra. Por todo el mundo se han conocido diversos tipos de polifonía; en otras partes se encuentra también la fusión sonora de muchos instrumentos, así como el canto a varias voces. En otras partes se han calculado y se conocen también todos nuestros intervalos racionales. Sin embargo, la música armónica racional - tanto el contrapunto como la armonía de acordes -, la formación del material sonoro sobre la base de las tres tríadas con la tercera armónica, nuestro cromatismo, nuestra enarmonía, interpretados desde el Renacimiento, no por la simple distancia sino de forma racional en el sentido de la armonía, nuestra orquesta con el cuarteto de cuerdas como núcleo y la organización del conjunto de los instrumentos de viento, el bajo continuo, nuestra notación musical [...], nuestras sonatas, sinfonías, óperas y, como medio para todas ellas, nuestros instrumentos esenciales, órgano, piano, violín, todo esto ha existido sólo en occidente - aunque en los sistemas musicales más diversos hayan existido la música de programa, las descripciones con medios musicales, la disonancia y el cromatismo como medio de expresión -." (p. 2; E.G., pp. 314-315). Pocos párrafos son tan ilustrativos como éste de la posición de Weber. En primer lugar, como casi siempre, el autor comienza refiriéndose a que no existe ningún condicionante fisiológico intrínseco que diferencie a occidente del resto del mundo. A menudo las condiciones de partida podían incluso favorecer al marco extraoccidental. En segundo lugar, y sin renunciar (como veremos después) a referirse a otros ámbitos artísticos, la música ofrece para nuestro autor un ejemplo muy expresivo de lo que él concibe por racionalización ${ }^{(30)}$. La forma en la que occidente organiza y desarrolla

(30) Sobre el tema de la música, consultar, Weber, Die rationalen und soziologischen Grundlagen der Musik (escrito en 1911 y publicado en Munich en 1921); E. Gavilán, 1997 (pp. 28-29); Chr. Braun, "The science of reality of music history: on the historical background of Max Weber's study of music", en S. Whimster, (ed.), Max Weber and the culture of anarchy, Londres, MacMillan, 1999, (pp. 178-195); o Wolfgang Schluchter, (ed.), Studie über Hinduismus und Buddhismus, Frankfurt, Suhrkamp, 1984, (pp. 15-19). 
algo tan abstracto como la música permite comprender la naturaleza de la diferencia que después se percibirá en la ciencia, en la economía, etc. En tercer lugar, el párrafo nos permite apreciar que cada ámbito cultural ha estructurado sus materiales musicales de un modo ni superior ni inferior al resto sino sólo diferente; ahora bien, cada uno ha llevado a cabo tal organización a partir de una serie de improntas y mecanismos que se plasman en el resto de sus manifestaciones culturales. Ahí es donde Weber incide en que occidente ha construido un desarrollo de la música coherente con el resto de sus desarrollos culturales sea en la física, en la matemática o en el cálculo mercantil.

Así seguirá la enumeración de áreas de la cultura donde occidente desarrolla su peculiar impronta: en el arte, sobre todo en la arquitectura; en la imprenta (cuyo uso y evolución fueron radicalmente diferentes, por ejemplo, a los de China); en el propio sistema de enseñanza y en el cultivo especializado de la ciencia, racional y sistemático, con especialistas que se integran en escuelas; en el funcionariado especializado, pilar del Estado moderno y de la economía moderna en occidente que encuadra toda la vida occidental y todas las condiciones técnicas y económicas de la misma en la carcasa (Gehäuse) de una organización de funcionarios especializados; en el estado estamental (Ständestaat) "rex et regnum", en el parlamento de representantes del pueblo elegidos periódicamente o en el "Estado" en el sentido de institución política con una constitución establecida de forma racional, un derecho racional y una administración orientada por reglas (leyes) establecidas de modo racional mediante funcionarios especializados. En otros ámbitos, pudieron darse esbozos que serían semejantes en alguna medida pero nunca iguales. "Eso ocurre también con el poder decisivo de nuestra vida moderna, el capitalismo" (p. 4; E.G., p. 316). Weber ubica al capitalismo dentro de un proceso complejo de racionalización (el occidental) en el que quizá tenga preponderaricia por su naturaleza económica, pero en el que no deja de ser una manifestación más, equiparable a las ya referidas. A continuación, la Vorbemerkung weberiana se dedicará a matizar los límites de dicho capitalismo. "Definámoslo (el capitalismo) - dirá el autor - con una precisión mayor de la habitual" (p. 4; E.G., p. 317). El autor distinguirá el capitalismo del mero "afán de lucro" ("Erwerbstrieb") que se da en toda clase de individuos y en toda clase de sociedades. El capitalismo se caracterizará precisamente por el sometimiento de ese impulso irracional: "Capitalismo es idéntico a búsqueda del beneficio, 
pero en una empresa capitalista racional y continua; es búsqueda del beneficio siempre renovado, de la 'rentabilidad'." (p. 2; E.G., p. 317). El capitalismo se apoya ante todo en la expectativa de beneficio mediante el aprovechamiento de las posibilidades de cambio, y por tanto pacíficamente. La acción capitalista, de este modo, se orientará al cálculo de capital; el cálculo es siempre en dinero; también la empresa capitalista podrá contar con factores convencionales o tradicionalistas en su interior, ahora bien, ésos tan sólo afectarán al grado mayor o menor de racionalidad de dicha empresa. "En esencia se trata simplemente de que la acción económica esté determinada por la orientación a comparar - por primitiva que sea la forma de la comparación - el resultado y la inversión, valorados ambos en dinero. En este sentido, ha habido 'capitalismo' y empresas 'capitalistas', incluso con tolerable racionalización del cálculo de capital, en todos los ámbitos culturales de la tierra hasta donde alcanzan los documentos económicos: en China, la India, Babilonia, Egipto, la antigüedad mediterránea, así como la época moderna. [...] la empresa capitalista y también el empresario capitalista, no sólo como empresario de ocasión sino también como empresario permanente son antiquísimos y tuvieron una difusión completamente universal." (p. 6; E.G., p. 319). De nuevo, vemos a Weber afincado en la percepción de la sutileza de las diferentes variables de la racionalización. "Sin embargo, occidente ha dado una relevancia única y, lo que la explica, tipos, formas y orientaciones que no existieron en ninguna otra parte."(p. 6; E.G., p. 319). Para Weber, en la época moderna, occidente conocerá un tipo de capitalismo diferente y que no se ha desarrollado en ningún otro lugar de la tierra, a saber, la organización racional-capitalista del trabajo (formalmente) libre. Aún así, la organización racional de la empresa orientada a las oportunidades del mercado y no a la especulación irracional o a la fortuna de la violencia política no es el único fenómeno específico del capitalismo occidental. "La organización racional moderna de la empresa capitalista no habría sido posible sin otros dos importantes elementos de su desarrollo: la separación de casa y empresa [...] y, estrechamente asociada a esa separación, la contabilidad racional." (p. 8; E.G., pp. 321). Aunque esa separación casa-empresa pueda darse en otros ámbitos (bazar oriental o ergasterios), se trata de simples esbozos comparados con la emancipación de la empresa moderna, porque faltan los medios internos de esta independencia, es decir, la contabilidad racional y la separación jurídica del patrimonio de la empresa y del patrimonio personal; o porque estas 
circunstancias sólo alcanzan un desarrollo muy elemental ${ }^{(31)}$. Todas estas peculiaridades del capitalismo occidental se han mantenido sólo por su vínculo con la organización del trabajo capitalista; también la comercialización (es decir, el desarrollo de los títulos de crédito y la racionalización de la especulación - la bolsa -) está vinculada a aquélla. Sin dicha organización capitalista del trabajo nada habría tenido el mismo alcance. Pero a

(31) Sin duda, habrá que tener muy en cuenta este tipo de razonamiento weberiano a la hora de calibrar lo apropiado o no de determinadas críticas vertidas sobre el autor alemán. Como vemos (y estamos hablando de su último texto), Weber no niega que en ámbitos culturales extraoccidentales se den formas económicas que apuntan en cierta medida a algo parecido al capitalismo occidental. No rechaza la idea de que existan en otras sociedades elementos que en determinadas circunstancias podrían convertirse en gérmenes del capitalismo. Lo que señala, en realidad, es que los desarrollos que se dieron en occidente sólo se dieron ahí. Y que mientras ese proceso se operaba en occidente, los esbozos extraoccidentales asimilables al capitalismo se anquilosaban en formas de desarrollo económicas menos dinámicas, menos eficientes ante la perspectiva de un dominio del mundo (Weltbeherrschung). La importancia de los estudios de Weber pasa por que no separa la racionalización económica de la que se experimenta en el resto de las esferas de la vida. Y, por tanto, no se trata sólo de que el capitalismo se dé en occidente como una perla rara nacida de forma espontánea a causa de una serie de circunstancias que se dan allí sino que el capitalismo es la vertiente socioeconómica del proceso general de racionalización que se lleva a cabo en occidente en todos los campos de la vida social en virtud a su peculiar lógica interna de desarrollo (Eigengesetzlichkeit). Si otros ámbitos culturales se acercan en cierta medida al capitalismo o si no lo hacen en absoluto depende sólo de un pesante cúmulo de circunstancias que, pese a todo, abocan a buen seguro y en buena medida a sus formas económicas a desarrollos económicos que tampoco tienen por qué confluir en algo parecido al capitalismo sino muy posiblemente, tras una pequeña fase de aproximación a aquél, podrían emprender un rumbo divergente. Considerar, como hacen por ejemplo buena parte de los críticos de $H \mathcal{E} B$, que Weber está limitando la inteligencia o cercenando las posibilidades de avance de las economías indias hacia el capitalismo por decir que cuando éste surge y se desarrolla en occidente y durante los siglos posteriores en el ámbito extraoccidental no se daba capitalismo ni se podía (se supone que exhibiendo de esa forma su radical etnocentrismo y falta de comprensión de ese ámbito) es no entender nada de lo que Weber escribió. Puesto que si volvemos tal argumento del revés, podríamos también acusar a Weber de que no es capaz de ver en su producción las condiciones que se daban en occidente para la expansión del modo de vida budista, por ejemplo, que se está desarrollando en algunos núcleos occidentales en la actualidad o que, quién sabe, podría desarrollarse en el futuro. 
su vez, dado que occidente es el único ámbito que ha conocido una organización racional del trabajo, también es el único que ha conocido un socialismo racional. "Ciertamente, al igual que el mundo ha conocido economía urbana, política de aprovisionamiento urbano, mercantilismo y política de bienestar de los príncipes, racionamientos, economía regulada, proteccionismo y teorías del laissez-faire (en China), ha conocido también economías comunistas y socialistas de muy diverso cuño: comunismo de origen familiar, religioso o militar, economía de socialismo de Estado (en Egipto), de tipo del cartel monopolista y también de organizaciones de consumidores de los modelos más diversos. Pero a pesar de que en todas partes hubiera privilegios de mercados urbanos, gremios, hermandades y todo tipo de distinciones jurídicas entre ciudad y campo, fuera de occidente faltaba el concepto de "burgués", y fuera del occidente moderno, el de "burguesía"; de la misma forma, faltaba también el "proletariado" como clase, y necesariamente tenía que ser así porque faltaba justamente la organización racional del trabajo libre como empresa." (p. 9; E.G., pp. 322-323). De igual modo, pese a que en todas partes se ha dado, en mayor o menor medida, algo semejante a la "lucha de clases", en todos los ámbitos, excepto en occidente faltará la gran contradicción moderna: gran empresario industrial y trabajador asalariado libre. Por ello, faltará a su vez toda la problemática del tipo de la del socialismo occidental moderno. Aquí se puede ver parte del diálogo de Weber con Marx y con el marxismo, la puntualización de Weber acota el terreno del marxismo a unas coordenadas espacio-temporales muy determinadas. Para Weber, parece resultar problemático retrotraer la imagen de la lucha entre socialismo y capitalismo a épocas o a ámbitos en los que había un marco sociocultural distinto del s. XIX.

Por tanto, para Weber, en una Historia Universal de la cultura, el problema central será el de la aparición del capitalismo de empresa burgués con su organización del trabajo libre. También la técnica influirá en el capitalismo. La racionalidad del mismo estará caracterizada, según él, por el carácter calculable de los factores técnicamente decisivos, base del cálculo exacto. Ahí reside la peculiaridad de la ciencia occidental, en especial, de las ciencias de la naturaleza fundamentadas en la matemática y la experimentación. Ciencia y técnica recibirán impulsos decisivos de las perspectivas capitalistas que se asocian a su explotación económica como premios. "Ahora bien, la aparición de la ciencia occidental no estuvo determinada por esas posibilidades. También los indios 
calculaban - lo hacían incluso con números posicionales -, practicaban el álgebra, inventaron el sistema de numeración posicional, pero todo ello no produjo en la India ni cálculo moderno ni balances. Sólo en occidente se puso la ciencia al servicio del capitalismo en desarrollo." (p. 10; E.G., p. 324). Si bien la matemática y la mecánica no estuvieron condicionadas por intereses capitalistas, en occidente, el empleo técnico de los conocimientos científicos estuvo condicionado por los premios económicos que se ponían en ello. Tales premios emanaban, no obstante de la peculiaridad del orden social en occidente. Entre los elementos fundamentales de ese orden estaba: la estructura racional del derecho y la administración, pues sin un derecho calculable y una administración sujeta a reglas formales puede ser posible el capitalismo comercial aventurero y especulativo y el capitalismo condicionado por la política, pero no podrá serlo ninguna empresa racional de economía privada con un capital permanente y cálculo seguro. " ¿Y por qué no hicieron lo mismo los intereses capitalistas en China o la India? ¿Por qué no se desviaron a esas vías de racionalización que son propias de occidente ni el desarrollo científico, ni el artístico, ni el estatal, ni el económico?" (p. 11; E.G., p. 325).

Será en este punto en el que el autor bucee en el término "racionalismo" y diga que existen diferentes "racionalizaciones": "Por ejemplo, hay 'racionalizaciones' de la contemplación mística, es decir, de un comportamiento que, visto desde otros ámbitos, es específicamente "irracional", tanto como racionalizaciones de la economía, de la técnica, del trabajo científico, de la educación, de la guerra, de la justicia y de la administración. Además se puede 'racionalizar' cada uno de estos ámbitos desde puntos de vista y objetivos muy diferentes. Lo que considerado desde uno es 'racional', puede ser 'irracional' desde otro." (p. 11; E.G., p. 325)(32). Aquí nos encontramos ante uno de los problemas esenciales de la teorización weberiana y ante una de las cuestiones que inexcusable-

(32) Este encuadre de la "racionalidad" en el dominio de lo subjetivo entronca sin duda con la propia idea general de cultura que el autor expone en su célebre ensayo sobre la objetividad Die "Objektivität" sozialwissenschaftlicher und sozialpolitischer Erkenntnis, 1904, (GAWL, pp. 146-214). En éste, Weber desarrollará sus ideas en torno a la esencia de la ciencia social sobre la base de dos suposiciones: La Sozialwissenschaft (ciencia social) ha de ser una Wirklichkeitswissenschaft (ciencia de la realidad) y una Kulturwissenschaft (ciencia de la cultura) que nos lleve a comprender, por un lado, el contexto y el significado cultural (Kulturbedeutung) de las diferentes manifestaciones de la realidad en su forma actual y, por otro, las causas de que históricamente se haya producido así y no de otro 
mente ha de tener en cuenta cualquiera que decida pensar sobre las ideas de este autor. "En todas las culturas ha habido racionalizaciones del tipo

modo. En tal ensayo, Weber definirá la cultura como "un segmento pensado y finito con sentido y significado desde el punto de vista del ser humano, que se extrae de entre la infinidad de acontecimientos sin sentido que se dan en el mundo" (p. 180). La condición fundamental de toda ciencia de la cultura no será, según él, que encontremos valiosa cierta cultura (o la cultura en general) sino que nosotros, los Kulturmenschen (hombres pertenecientes a una cultura) tengamos la capacidad y la voluntad de tomar una posición consciente ante el mundo y de dotarle de un sentido. Sea cual sea dicho sentido, nos basaremos en él para juzgar los fenómenos de la convivencia humana y para tomar una postura positiva o negativa. Al margen del contenido de esa postura, tales fenómenos tendrán para nosotros un significado cultural y ahí radicará la base de su interés científico. Weber se curará en salud frente a malentendidos como el de atribuir un significado cultural sólo a aquellos fenómenos que se consideran "valiosos"; por ello, considerará igualmente importantes, en cuanto que fenómenos culturales, a la prostitución, a la religión o al dinero. Todo conocimiento de la realidad cultural se llevará siempre a cabo, según nuestro autor, bajo unos puntos de vista específicos; no hay que olvidar que para él, los individuos estamos "anclados" en una serie de ideas de valor (Wertideen). Así, el historiador o el sociólogo distinguirán lo esencial de lo accesorio refiriendo los procesos de la realidad a unos valores culturales universales y tratando de extraer las relaciones que tienen un significado para nosotros. De la inmensidad de posibilidades de análisis que presenta la realidad, el especialista destacará tan sólo algunos componentes nimios de la misma, precisamente aquéllos que le interesan. Las obras resultantes, por tanto, no serán sino un reflejo de la personalidad de sus autores. Sin las ideas de valor del investigador no habría ningún principio de elección de la materia ni ningún conocimiento de la realidad individual que tuviera sentido. Por tanto, para Weber, el conocimiento científico-cultural estará ligado a unas premisas subjetivas, pues tan sólo se ocupa de aquellos elementos de la realidad que se hallan en relación con los procesos a los que dotamos de un significado cultural. En la cultura, domina el perspectivismo. Aun cuando parezca una paradoja, sobre él se basa la idea weberiana de la ciencia de la cultura: no puede darse un análisis científico de la vida cultural que sea "objetivo" a secas... independiente de puntos de vista especiales y "unilaterales"(p. 170); los fenómenos culturales sólo pueden ser escogidos de entre la inacabable multiplicidad de lo real y hechos objetos de la investigación, en tanto que su existencia y la forma que adoptan históricamente conciernen, directa o indirectamente, a nuestros intereses culturales. Por tanto, dado que siempre se parte de un punto de vista subjetivo para atribuir "racionalidad" o "irracionalidad" a una cultura, queda de nuevo de manifiesto la clara voluntad weberiana de huir de epítetos etnocentristas a la hora de tratar las culturas no occidentales. 
más diverso en diferentes ámbitos. Lo que caracteriza su diferencia en la historia de la cultura son ante todo las esferas y la dirección de la racionalización." (pp. 11-12; E.G., p. 325). Con esta afirmación, Weber deja claro que todos los ámbitos culturales, es decir, los occidentales y cada uno de los no occidentales, "racionalizan" las esferas de su vida en uno $u$ otro sentido de acuerdo con una serie de presupuestos que experimentan a su vez un desarrollo autónomo en cada ámbito. Ninguna de esas racionalizaciones será en sí superior a las otras, aunque, como es evidente, de cada una de ellas se derivarán diferentes modos de situarse ante el mundo que harán que unas logren alcanzar una ventaja clara frente a las otras que, como en el caso del capitalismo puede acabar en la dominación de las restantes, como ocurrió de forma efectiva en el colonialismo llevado a cabo por Europa.

A partir de ahí, Weber propondrá como primera tarea distinguir la singularidad del racionalismo occidental y, dentro de éste, del racionalismo occidental moderno, y explicar su aparición. Esta explicación habrá de considerar, por un lado, las condiciones económicas pero, por otro, habrá de tratar de no desatender ni a la técnica y el derecho racionales ni a la capacidad y la disposición de los hombres a determinadas formas de Lebensführung (modo de vida) práctico-racionales. Frente a la teoría materialista, Weber insiste en el papel esencial de las ideas y de las creencias a la hora de analizar la acción social. "Donde esa regla de conducta se ve obstruida por obstáculos de tipo espiritual, el desarrollo de un modo de vida económico racional tropieza también con fuertes resistencias internas. Entre los más importantes elementos conformadores del modo de vida se han contado siempre en el pasado los poderes mágicos y religiosos y las concepciones éticas del deber ancladas en la creencia en esos poderes." (p. 12; E.G., p. 325). En este texto tan tardío, nuestro autor continúa en la línea ya establecida a principios de los años noventa del s. XIX, cuando estudiara a los campesinos alemanes del este del Elba, continuada en la $P E$ y que tendrá sus desarrollos teóricos fundamentales en textos como la aludida Einleitung. Weber se dedicará, en los GARS a revisar aquellas concepciones éticas que guían las conductas, especialmente las conductas económicas, con arreglo a la creencia en determinados poderes. Es ahí donde el autor lleva a cabo una pequeña explicación de lo que pretende con la publicación de sus GARS. Dirá haber colocado al frente dos ensayos antiguos: la $P E$ y las Protestantische Sekten que "intentan acercarse en una cuestión importante al aspecto del problema generalmente más difícil de captar: 
cómo determinadas creencias religiosas condicionan la aparición de una 'mentalidad económica' (Wirtschaftsgesinnung), de un 'talante' ('Ethos'), de una forma económica. Se trata del ejemplo de las relaciones del talante económico moderno con la ética racional del protestantismo ascético. En esos ensayos se sigue sólo un aspecto de la relación causal." (p. 12; E.G., p. 326). A continuación, dice haber colocado los ensayos de la WEWR, que constituirán una panorámica de las relaciones de las culturas religiosas más importantes respecto a la economía y la estratificación social de su mundo. Éstos, según él, intentarán seguir ambas relaciones causales para encontrar los puntos de comparación con el desarrollo occidental que analizará más tarde. "Sólo así se puede acometer con relativa claridad el establecimiento causal de aquellos elementos peculiares de la ética económica religiosa occidental, a diferencia de otros." (pp. 12-13; E.G., p. 326).

El autor, consciente de las interpretaciones erróneas que puede acarrear una lectura poco profunda de su obra, se adelanta a ellas y expone que estos ensayos de los GARS no tratan de ser análisis culturales exhaustivos y generales sino que lo que pretenden es acentuar en cada ámbito cultural lo que se contraponía y se contrapone al desarrollo de la cultura occidental. Weber estudia la diferencia, no el cuadro completo, y así se referirá en esencia a los puntos de vista que resultan de importancia para el desarrollo occidental. Ese desarrollo occidental no resulta en Weber algo evidente sino que es algo tan extraño como lo que ocurre en el resto de culturas. Nuestro autor negocia la diferencia y emplea los recorridos históricos por otras culturas para entender mejor la solución occidental a determinados problemas, fundamentalmente religiosos, y la trascendencia de estas soluciones en las diferentes esferas de la vida, principalmente en la socioeconómica. Weber es consciente de lo limitado de su objetivo. "El sinólogo, el indólogo, el especialista en estudios semíticos, el egiptólogo no encontrará naturalmente en ellos conocimientos nuevos para él. Sólo sería deseable que no encontrara nada esencial que tenga que condenar como empíricamente equivocado. El autor no puede saber hasta qué punto ha conseguido acercarse a ese ideal dentro de lo que es capaz un no especialista. Es absolutamente evidente que alguien obligado a emplear traducciones y que para la valoración de las fuentes monumentales, documentales o literarias ha de orientarse por una literatura especializada, con frecuencia llena de controversias, alguien que no puede juzgar su valor de forma autónoma, tiene todos los argumentos para considerar con mucha modestia el valor de su trabajo. Tanto más 
cuando la extensión de las traducciones existentes de las 'fuentes' genuinas (es decir, inscripciones y documentos) es todavía reducidísima (en particular en lo referente a China) en relación a lo que existe y es importante." (p. 13; E. G., p. 326). Por todo ello, Weber considera a sus artículos como algo provisional, en especial las partes dedicadas a Asia; $y$, pese a conocer el hebreo, considera insuficiente su conocimiento de esta lengua. Para él, son los especialistas los que habrán de dar un juicio definitivo. "Estos ensayos se han escrito exclusivamente porque hasta ahora no existían, como es lógico, análisis de especialistas con ese objetivo concreto y desde esos puntos de vista concretos. Están destinados a ser pronto "superados" en un sentido y en una medida incomparablemente mayores a lo que ocurre en última instancia con todo trabajo científico. En trabajos de este tipo no puede evitarse, por discutible que sea, una invasión comparativa en otras especialidades; pero por ello se ha de concluir con gran resignación en relación al nivel alcanzado." (pp. 13-14; E.G., p. 327). Sin tener en cuenta estas reflexiones no se puede acometer la lectura de los GARS ni, en general, de los escritos de Weber sobre la $R S$. En el final de la Vorbemerkung, late sin duda el espíritu de Wissenschaft als Beruf $(W a l s B)^{(33)}$. El autor mira a su propia obra con una cierta melancolía, con un cierto talante trágico. Su obra está condenada a ser superada en breve; él es consciente de ello y, sin embargo, la lleva a cabo por que el hacerlo es su "trabajo por vocación", su Beruf. En línea con WalsB y tratando de adelantarse a las críticas, destacará el papel del especialista frente al diletante. El diletante también ha aportado algo a la ciencia, pero no puede ser el modelo de la misma. Él se sitúa al margen del diletantismo pese a lo modesto - dice él - de su trabajo. "El que quiera espectáculo que se vaya al cine", dirá criticando trabajos asimilables al suyo (exceptuando expresamente algunos como los de Jaspers y Klages). Tampoco pretende con ellos que la comparación muestre las virtudes de unas culturas y los vicios de otras. "Eì que quiera un 'sermón' que se vaya al conventículo", dirá pues la máxima que ha guiado sus ensayos ha sido la de no llevar a cabo una comparación valorativa de las culturas

(33) En WalsB puede leerse "Cada uno de los que estamos en la ciencia, en cambio, sabe que lo que ha trabajado habrá envejecido en diez, veinte o cincuenta años. Sí, ése es el destino; ése es el sentido del trabajo de la ciencia, al que él se somete y se entrega, en un sentido totalmente específico frente a todo el resto de elementos culturales para los que por lo demás aún vale ese sentido: cada "Erfüllung" científica supone nuevas cuestiones y anhela (will) ser "superada" y quedar desfasada." (WL, p. 592). 
tratadas. "Es verdad que el curso de los destinos de la humanidad conmueve a quien tiene la visión de un fragmento, y lo emociona. Pero hará bien en guardar sus pequeños comentarios personales para sí, como se hace ante la visión del mar y de la alta montaña - a no ser que uno se crea llamado y dotado para la forma artística o para el desafío poético -. En la mayoría de los restantes casos mucha cháchara sobre 'intuición' no encierra otra cosa que falta de distancia respecto al objeto que se ha de juzgar, igual que la misma actitud respecto a la persona." (p. 14; E.G., p. 327). Weber está convencido de que, en particular para el estudio de Asia, hubiera habido de recurrir a la investigación etnográfica, sabe que eso se le criticará pero reconoce sus límites; espera poder llenar ese vacío a través de una elaboración sistemática de la sociología de la religión, algo que salvo los valiosos esbozos de Wirtschaft und Gesellschaft ya no pudo llevar a cabo. No obstante, reconoce que haber llevado a cabo tal empresa en el marco de los GARS habría resultado tal vez demasiado puesto que a lo que cree él que había de dedicarse es a exponer lo mejor posible los puntos de comparación con "nuestras culturas religiosas occidentales". Finalmente, nuestro autor considera que también habría una vertiente antropológica del problema, a saber, si la herencia biológica tiene algo que ver en que sólo en occidente se den determinados tipos de racionalización, por ejemplo; y dice que, pese a los avances de la antropología, no es capaz aún de ver la forma de captar su contribución al trabajo desarrollado por él. "Tendrá que ser justamente una de las tareas del trabajo sociológico e histórico exponer todas esas influencias y nexos causales que son explicables satisfactoriamente a través de reacciones a destinos y contornos. Sólo cuando la neurología y psicología comparativas de las razas superen sus inicios presentes, muy prometedores en aspectos concretos, si lo hacen, puedan quizás esperarse resultados satisfactorios también para ese problema. De momento parece faltar ese presupuesto, y remitir a la "herencia" sería una renuncia prematura al grado hoy quizá posible de conocimiento y un desplazamiento del problema a factores (todavía) desconocidos." (pp. 15-16; E.G., p. 328) ${ }^{(34)}$.

(34) Puede que haya quien, como J. M. Blaut (ver 2000, p. 20), vea en este párrafo una prueba del racismo de Weber. Nosotros pencibimos en él justamente lo contrario... el racismo carece de herramientas mínimamente aceptables para el estudio de las diferencias culturales. Con esto, nuestro autor salía al paso de muchos de los que en su época loaban la precisión de los estudios de las razas, cuyas consecuencias inmediatas no hace falta evocar aquí. 
En definitiva, podríamos decir que la Vorbemerkung es, de algún modo, el momento en el que nuestro autor describe cómo un desarrollo particular se convierte en universal. La racionalización occidental, a diferencia de la india o la china, ha creado un cosmos fundado en su peculiar razón que se adapta como un guante a la idea de dominación del mundo (Weltbeherrschung $)^{(35)}$. En tanto en cuanto los resultados de esa dominación son los que imperaban en el tiempo de Weber y los que siguen imperando hoy, la descripción universal del mundo desplegada por nuestro autor tratará de ver cómo pudo generarse y cómo pudo contar con las herramientas necesarias para imponerse al resto. La $R S$ de Weber, su particular "Historia Universal" no da cuenta de ningún progreso de la humanidad ni de ningún "desarrollo hacia lo mejor", tan sólo habla de cómo la Eigengesetzlichkeit occidental contó con medios científicos, económicos, sociales, técnicos, etc., más efectivos que los desplegados por las otras Eigengesetzlichkeiten. En una lectura weberiana, la modernidad, el proceso de colonización, las cámaras de gas o la "globalización" no serían nada más que un apéndice lógico de la evolución a la que había llevado la peculiaridad occidental. No parece fácil encontrar en esta constatación ningún entusiasmo por parte de nuestro autor; más bien al contrario. En el fondo de su relato, late la duda: ¿Son el significado y la validez de los fenómenos culturales desarrollados en occidente una "realidad" para alguien más que para el "nosotros" nacido en Europa? ¿No será acaso el dominio del mundo sólo un espectro del sueño de la razón del sujeto occidental? ¿Tiene la "Historia Universal" el color blanco de occidente o se trata acaso de que es así como a la mirada occidental le gusta representárselo?

(35) Gabriele Cappai señala que la orientación hacia la Weltbeherrschung se expresa principalmente a través de dos fenómenos, la objetivación (Versachlichung) de las relaciones humanas y el desencantamiento (Entzauberung) de la relación entre el ser humano y el mundo natural mediante la ciencia (como puede percibirse en $W a l s B$ ). Ahora bien, Weber no tratará de explicar con amplitud la génesis de la orientación hacia la dominación práctica del mundo, lo que habría supuesto una genealogía de la ciencia (ver Gabriele Cappai, Religion und Welt. Zum Verhältnis von religiöser Ethik und Welt bei Max Weber, Nürnberg, Verlag Peter Athmann, 2000, pp. 80-82). 